\title{
A review of MIS 7 and MIS 5 terrace deposits along the Gulf of Taranto based on new stratigraphic and chronological data
}

\author{
Vincenzo De Santis $(*)$, Massimo Caldara $\left({ }^{*}\right)$, Trinidad Torres $(* *)$, José E. Ortiz $(* *)$ \\ \& Yolanda Sánchez-Palencia $(*)$
}

\section{ABSTRACT}

We performed detailed geological and geomorphological analyses on a well-exposed series of marine terrace deposits located along a coastal area from the city of Taranto to the Bradano River in the northern Gulf of Taranto (southern Italy). Absolute dating was performed by applying amino acid racemisation (AAR) to ostracod shells and isoleucine epimerisation (D-aTle/L-Tle) to Glycymeris sp. shells. The combination of field geological surveys, remote sensing, digital terrain model analysis, and absolute dating allowed us to study a large number of stratigraphic sections as well as recognise and map three terrace deposits in the Apulian sector of the Gulf of Taranto that date to MIS 7.3, MIS 7.1 and MIS 5. A peculiar feature of the MIS 7.1 terrace deposit is the presence of biohermal and biostromal limestones rich in Cladocora caespitosa, calcareous algae and bryozoans; this feature contrasts with general context of the prevailing siliciclastic deposits.

Based on currently available data, we propose two hypotheses regarding the MIS 5 terrace deposit: 1) the MIS 5 terrace formed entirely during MIS 5.5; and 2) the MIS 5 terrace is a set of terraces that correlates to MIS 5.5, 5.3 and 5.1, in which the scarps and abrasion platforms have been partially masked by the superimposition of the so-called givoni, ridges that are elongated sub-parallel to the coastline. Our data, combined with an extensive critical review of age dates in the literature, allow us to exclude the presence of an emerged marine terrace deposit of MIS 3 .

We calculate the uplift rates of the MIS 7.3, 7.1, 5.5 and 5.3 palaeoshorelines. In the west sector, the mean uplift rates calculated for the recognised inner edges are MIS $7.3=0.65 \mathrm{~mm} / \mathrm{a}$, MIS $5.5=$ $0.39 \mathrm{~mm} / \mathrm{a}$, MIS $5.3=0.31 \mathrm{~mm} / \mathrm{a}$; in the central sector the rates are MIS $7.3=0.485 \mathrm{~mm} / \mathrm{a}$, MIS $7.1=0.37 \mathrm{~mm} / \mathrm{a}$, MIS $5.5=0.35 \mathrm{~mm} / \mathrm{a}$, MIS $5.3=0.26 \mathrm{~mm} / \mathrm{a}$; in the east sector the rates are MIS $7.3=0.39$ $\mathrm{mm} / \mathrm{a}$, MIS $5.5=0.25 \mathrm{~mm} / \mathrm{a}$, MIS $5.3=0.21 \mathrm{~mm} / \mathrm{a}$. These uplift rates show a uniform decreasing trend in time and space, proceeding from the western to the eastern sector, which allows us to hypothesise a slowing of the uplift phase characterising the foredeep, which began in the middle Pleistocene.

KEY WORDS: marine terrace deposits, amino acid racemisation, allo-isoleucine epimerisation, southern Italy, MIS 5, MIS 7.

\section{INTRODUCTION}

The Taranto Gulf (Apulia Region, southern Italy) is an exemplary case for documenting the development of terracing phases and the interaction between tectonic movement and glacio-eustatic fluctuations.

(*) Dipartimento di Scienze della Terra e Geoambientali, Via Orabona 4, Università degli Studi di Bari "Aldo Moro", 70125 Bari, Italy.

(**) Biomolecular Stratigraphy Laboratory, Madrid School of Mines, C/Rios Rosas 21, E-28003 Madrid, Spain.

Corresponding author e-mail: vincenzo.desantis@uniba.it.
The great staircase of Pleistocene marine terraces in the Gulf of Taranto, which reaches a width of approximately $25 \mathrm{~km}$, has attracted the attention of geomorphologists and sedimentologists for many decades. However, no consensus has been reached regarding the number, genesis, or age of the terraces.

In addition to the usual obstacles to the development of an unambiguous chronology of terrace formation, another obstacle in our study area is that the inner edges are often masked by colluvial material and/or by the so-called givoni (singular: givone) (Boenzi et alii, 1977; Bentivenga et alii, 2004b), which are ridges elongated sub-parallel to the coastline and have a lengths of several kilometres. The givoni are interpreted as former beach ridges, barriers or spits (DE SANTIS \& CALDARA, submitted).

As a result, many researchers have mechanically assigned a terrace to each highstand peak without the use of absolute ages, relying only on the few chronological data that are available, especially for the youngest terraces; moreover, chronological data are often interpreted differently according to the researchers.

The main goal of our study was to develop a complete description of the youngest marine terrace deposits preserved in the Apulian sector of the Gulf of Taranto, including their stratigraphy, ages, and palaeoenvironmental descriptions. In particular, we provide new chronological data based on the Amino Acid Racemisation dating method and discuss the results together with previous ages that have been obtained in this area. Finally, we provide a new assessment of the local vertical movements.

\section{GEOLOGICAL SETTING AND PREVIOUS RESEARCH}

This study focused on the lower marine terrace deposits, which can be observed above the present coastal plain between the city of Taranto and the Bradano River (Apulia Region, southern Italy). From a geodynamical point of view, this territory is within to the Bradanic Trough foredeep, which formed during the Neogene between the Apennine chain and the Apulian foreland (Fig. 1).

In particular, the Plio-Pleistocene was characterised by two geodynamic phases (RicchetTI et alii, 1992). In the first phase, the westernmost sectors of the Apulian Foreland underwent strong subsidence (DogLIoni et alii, 1994) because of subduction beneath the Apennine chain. Thus, wide sectors of the foreland evolved into a foredeep (Bradanic Trough). In this context, a Bradanic Trough sedimentary cycle (Ricchetti, 1967; Azzaroli et alii, 1968; 


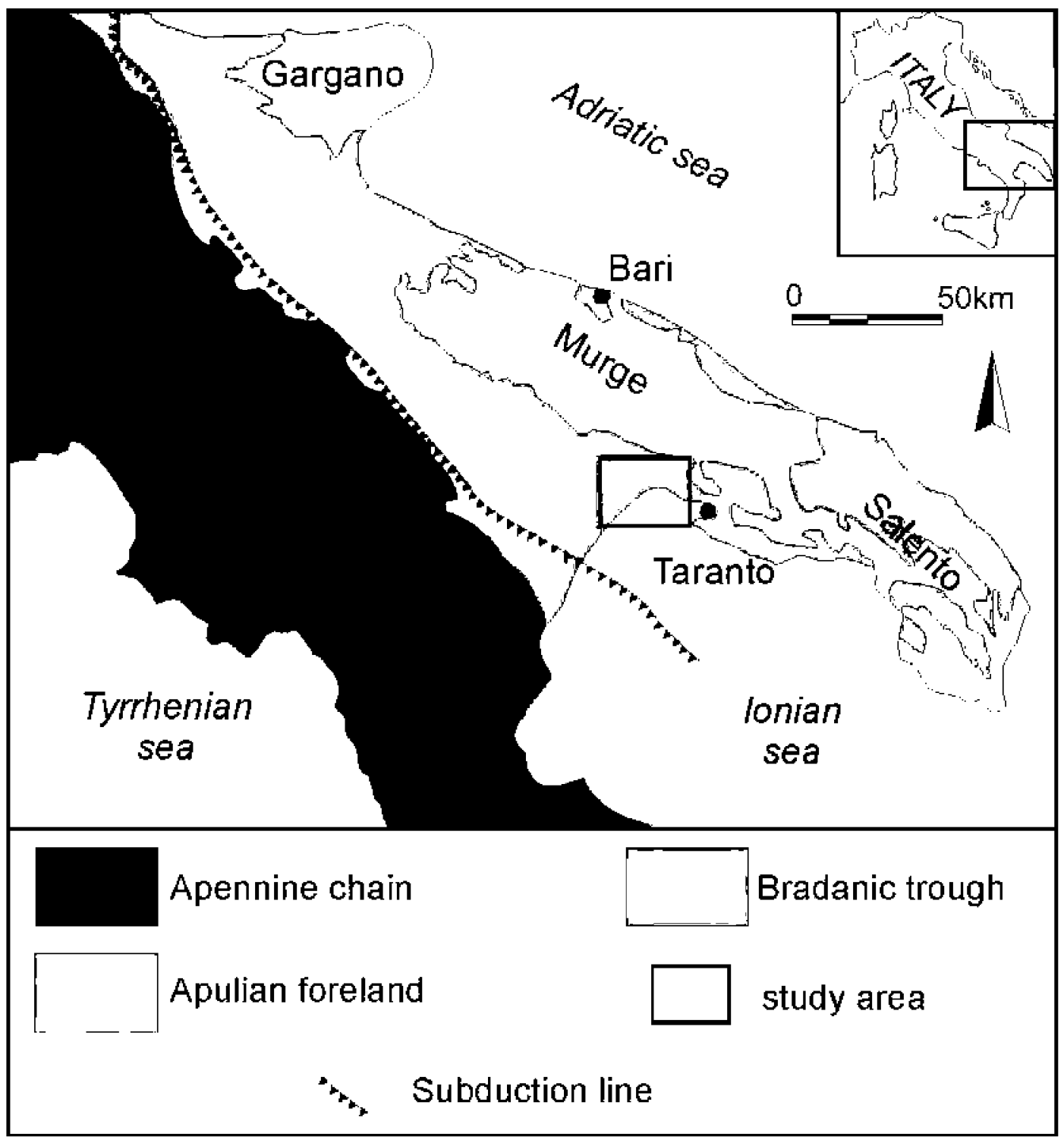

Fig. 1 - Main geological domains of the southern Italy and location of the study area.

Ricchetti, 1981; Ricchetti et alii, 1992) began to accumulate, culminating in silty clay hemipelagic deposits (the argille subappennine unit, ASP). In the second geodynamic phase (from the middle Pleistocene), the entire Apulian Foreland and Bradanic Trough were uplifted (RIcchETTI et alii, 1992; Doglioni et alii, 1994, 1996); the regressive deposits of the Bradanic Trough cycle and/or the marine and continental terrace deposits record this process (CIARANFI et alii, 1992). Glacio-eustatic sea level oscillations occurred together with the uplift, which complicated the mechanism of regression.

Boenzi et alii (1977) attempted to describe and characterise wide portions of the sequence of Ionian Sea marine terraces; they were followed by BRÜCKNER (1980a,b, 1982), Амато et alii (1997), Cucci \& CinTi (1998), Bianca \& Caputo (2003), Ferranti et alii (2006), Zander et alii (2006), and Santoro et alii (2010). The works of some authors focused on descriptions of single outcrops. In the sections located within our study area, BoENzI et alii (1985; Tab. 1) and Caldara (1987) described the Ponte del Re section (at elevations between 20 and $30 \mathrm{~m}$ a.s.l. in the inland Castellaneta Marina location) and assigned it to
MIS 5.5 due to the presence of the "senegalese fauna", which includes specimens of Strombus bubonius (now Persististrombus latus). Laviano \& PennetTa (1980) described the Fontana del Fico section (between ca. 30 and $40 \mathrm{~m}$ a.s.l.) and correlated it (likely) to the MIS 7.

According to BRÜCKNER (1983), PIERI et alii (1996), and Tropeano et alii (2002), the sequence of marine terrace deposits along the Gulf of Taranto is a regressive, coarsening-upward sedimentary body consisting of sand and conglomerate beds, unconformably overlying the ASP unit.

Authors have interpreted the terrace sequence along the Taranto Gulf as having resulted from interactions between regional Quaternary land uplift and glacio-eustatic sea level fluctuations. However, Bentivenga et alii (2004a,b) disagreed and interpreted the entire terrace sequence as a single middle Pleistocene terrace under the assumption that normal faults related to large-scale gravitational processes offset the single terrace and shifted its fragments to different elevations.

WESTAWAY \& BRIDGLAND (2007) investigated the rates and magnitudes of the Late Pliocene-Pleistocene uplift 
at key localities of Basilicata and Calabria using fluvial and marine terraces. In particular, for the Pisticci marine terrace staircase, the nearest to our study area, they establish that all the scarps depicted by BENTIVENGA et alii (2004) are real, but the bluffs marking the inner edges of marine terraces are not normal fault scarps; thus, they suggested a staircase of 12 marine terraces that formed during different marine highstands during the Pleistocene; the final two ( $B=$ MIS $5 \mathrm{e}$, inner edge at 40 $\mathrm{m} ; \mathrm{A}=$ MIS $5 \mathrm{a}$, inner edge at $25 \mathrm{~m}$ ) were consistent with the amino acid dating evidence (e.g., Dai Pra \& HEarty, 1992) and the 'Senegalese' fauna. Finally, they concluded that uplift rates show strong lateral variations, reaching maxima of $1 \mathrm{~mm} / \mathrm{a}$ or more in the southern Apennines, and a maximum value of ca. $0.55 \mathrm{~mm} / \mathrm{a}$ at the Pisticci marine terrace staircase.

CAPUTO et alii (2010) performed a detailed morphotectonic analysis of terraces along the Ionian coast of southern Italy. A major result of that research was a reconstruction of the geometry of the marine surfaces that documents the presence of 18 palaeoshorelines and provides evidence of strong regional uplift. Each terrace was correlated to a highstand sea level peak, thus dating the highest/oldest terrace to ca. $600 \mathrm{ka}$ (MIS 15). In this work, the ages of most of the terraces and their associations with highstands were inferred based on 4 dated terraces: Policoro (BRÜcKner, 1980a; DAI PRA \& Hearty, 1992; Belluomini et alii, 2002; Zander et alii, 2006), Metaponto 3 (not present in our study area; CAPUTO et alii, 2010), San Teodoro (Amato et alii 1997; Belluomini et alii, 2002; Zander et alii, 2006), and San Basilio (DAI PRA \& Hearty, 1992; BELLuomini et alii, 2002; Zander et alii, 2006). More recently, Giola et alii (2016) recognised eleven marine terraces (MT1 to MT11 from the youngest to the oldest) and inferred their ages using a critical revision of the chronological data that are available in the literature without discussing them.

Focusing specifically on our study area (Tab. 1):

1) Boenzi et alii (1977) identified four terraces and assigned them to a post-Calabrian age without providing additional details;

2) BRÜCKNER (1980a, b; 1982) identified three terraces (T1, T2/T3, T4/5) and dated the lower one by applying the U/Th method to mollusc shells. Absolute ages of $110 \pm 10 \mathrm{ka}$ (at Cozzo Marziotta, within our study area; Fig. 2), $75 \pm 7 \mathrm{ka}$ and $63 \pm 3 \mathrm{ka} \mathrm{BP}$ (at Petrulla, outside our study area) were subsequently obtained; and

3) CAPuTo et alii (2010) identified four terraces (above the Holocene coastal plain, referred to as MIS 1), which are (from oldest to youngest; Tab. 1) the Bernalda (MIS 7.1) Marconia 1 (MIS 5.5), San Basilio (MIS 5.3), San Teodoro (MIS 5.1), and Policoro terraces (MIS 3.3).

\section{METHODS}

The research methods consisted of the following steps:

1) All previous relevant geomorphological literature was collected and published maps of the terraces were reviewed;

2) Remote sensing analysis was performed using various sets of stereographic pairs of aerial photos that were taken in different years and at different scales, and a digital terrain model was created based on a 1:5.000-scale technical regional map; and
3) Detailed and systematic ground control was established based on intensive field surveys.

A fundamental assumption that we accepted is the correlation between the inner edge of each terrace and the interglacial-interstadial peaks (LAJOIE, 1986).

Following the definitions provided by CARoBEnE (1980), we surveyed the upper surfaces of the terrace deposits, the results of which are shown in Fig. 2, and we distinguished the true inner edges and edges masked by continental deposits wherever possible.

In the present study, we performed amino acid racemisation dating (AAR) on ostracod valves and Glycymeris shells. We followed the methods applied in our previous work on marine and alluvial terrace deposits in the Apulia Region (CALDARA et alii, 2013; De SANTIS et alii, 2010; 2013; 2014a, b). The extensive use of AAR has allowed researchers to establish a general aminostratigraphical framework of Pleistocene shorelines in the Mediterranean Basin. In some cases, age calculation algorithms have been developed (ORTIz et alii, 2004), although the use of aminozones has permitted the use of more general applications (HEARTY et alii, 1986; Hearty, 1987; Dai Pra \& Hearty, 1992; Hearty \& Dai Pra, 1992; TORRES et alii, 2000).

Following the preparation protocol described by $\mathrm{D}_{\mathrm{E}}$ SANTIS et alii $(2010 ; 2013)$, a certain number of translucent ostracod shells were selected from each bed (analytical samples, Tab. 2). For Glycymeris shells, a hollow diamond drill was used to remove discoid analytical samples ( 8 $\mathrm{mm}$ in diameter; Tab. 3) from an area near the beak of the shells (Torres et alii, 2013). Peripheral parts with visible weathering (approximately 20-30\%) were removed after chemical etching with $2 \mathrm{~N} \mathrm{HCl}$. Afterwards, samples weighing 10-20 $\mathrm{mg}$ were selected and analysed.

We used the $\mathrm{D} / \mathrm{L}$ ratios of aspartic acid and glutamic acid of ostracod shells for 173 analytical samples from 43 beds (Tab. 2). We used the isoleucine epimerisation values (D-aIle/L-Ile, Tab. 3) for 23 analytical samples of Glycymeris shells from 5 beds, as they are commonly used for dating in the Mediterranean region (Torres et alii, 2013). For the dating of the ostracod samples, we applied the age calculation algorithms developed by OrTIz et alii (2004). The age of a single bed was the average of the numerical ages obtained for the Asp and Glu D/L values measured in their samples. The age uncertainty was the standard deviation of all values obtained.

We rejected samples from 4 beds (TM5/5e, TM5/8c, TM6/2d, and TM6/3c) because their Asp and Glu D/L values were outside the $2 \sigma$ range of the group (cf. HEARTY et alii, 2004; KosniK \& KaUfman, 2008).

Among the remaining numerical ages, we also rejected ages from thirteen further beds that had standard deviations that were greater than or equal to $25 \%$ of the mean value because of their lack of usefulness for identifying a precise stage or substage.

To determine the AAR age of a specific bed, several samples are usually analysed rather than a single sample (e.g., U/Th and ${ }^{14} \mathrm{C}$ ages consider only one analytical sample). Moreover, according to Murray-Wallace (1995), intra-fossil and inter-fossil errors account for a coefficient of variation of approximately 20\%. Likewise, other non-quantified errors are linked to taphonomy (time averaging, reworking) and must be considered through sedimentological interpretation. Therefore, these facts 
TABLE 1

Summary of all data needed for the history of uplift in our study area. West sector (W): left side of Bradano River; Central sector (C): close to Lato River; East sector (E): east of Lenne River.

\begin{tabular}{|c|c|c|c|c|c|c|c|c|}
\hline \multirow{2}{*}{ MIS } & \multirow[b]{2}{*}{ Terrace name } & \multirow[b]{2}{*}{ Author } & \multicolumn{3}{|c|}{ Present inner edge elevation (m) } & \multirow[b]{2}{*}{$\begin{array}{l}\text { Dates or constraints used to assign a } \\
\text { stage or a substage }\end{array}$} & \multirow[b]{2}{*}{$\begin{array}{c}\text { Site of } \\
\text { datings }\end{array}$} & \multirow[b]{2}{*}{$\begin{array}{l}\text { Uplift rate } \\
(\mathrm{mm} / \mathrm{a})\end{array}$} \\
\hline & & & $\begin{array}{l}\text { West } \\
\text { sector } \\
(\mathrm{W})\end{array}$ & $\begin{array}{l}\text { Central } \\
\text { sector } \\
\text { (C) }\end{array}$ & $\begin{array}{l}\text { East } \\
\text { sector } \\
\text { (E) }\end{array}$ & & & \\
\hline \multirow[b]{2}{*}{3.3} & \multirow[b]{2}{*}{ Policoro } & \multirow{2}{*}{$\begin{array}{l}\text { CAPUTO } \\
\& \text { BIANCA } \\
(2009) \\
\text { CAPUTO } e t \\
\text { alii }(2010)\end{array}$} & \multirow[b]{2}{*}{$\sim 15$} & \multirow[b]{2}{*}{$\sim 12$} & & $\begin{array}{c}75 \pm 7 \text { and } 63 \pm 3 \mathrm{ka} \text { from U/Th } \\
\text { (BRÜCKNER, 1980a); between } 73.8 \pm 6.5 \\
\text { and } 49.4 \pm 3.8 \mathrm{ka} \text { from OSL (ZANDER et } \\
\text { alii, 2006) }\end{array}$ & LP & \multirow[b]{2}{*}{$0.8-1$} \\
\hline & & & & & & $\begin{array}{c}54.2 \pm 6.5 \text { ka from empirical relationship } \\
\text { between D/L ratios and U/Th absolute } \\
\text { ages of BELLUOMINI et alii (2002) applied } \\
\text { to D/L ratio of } 0.29 \pm 0.02 \text { (DAI PRA \& } \\
\text { HEARTY, 1992) }\end{array}$ & SN & \\
\hline \multirow{4}{*}{5.1} & \multirow[t]{2}{*}{ San Teodoro } & \multirow[t]{2}{*}{$\begin{array}{l}\text { CAPUTO et } \\
\text { alii }(2010)\end{array}$} & \multirow[t]{2}{*}{-30} & \multirow[t]{2}{*}{-25} & & $\begin{array}{c}70.3 \pm 3.2 \text { ka from empirical relationship } \\
\text { between } \mathrm{D} / \mathrm{L} \text { ratios and } \mathrm{U} / \mathrm{Th} \text { absolute } \\
\text { ages of BELLUOMINI et alii (2002) applied } \\
\text { to } \mathrm{D} / \mathrm{L} \text { ratio of } 0.34 \pm 0.01 \text { (AMATo et alii, } \\
1997 \text { ) }\end{array}$ & LM & \multirow[t]{2}{*}{$0.6-0.8$} \\
\hline & & & & & & $\begin{array}{c}81.4 \pm 7.2 \text { and } 59.8 \pm 5.5 \mathrm{ka} \text { from OSL } \\
\text { (ZANDER et alii, 2006). Considered a } \\
\text { mean of } 70.6 \mathrm{ka}\end{array}$ & ST1 & \\
\hline & \multirow{2}{*}{$\mathrm{T} 1$} & \multirow{2}{*}{$\begin{array}{l}\text { BRÜCKNER } \\
(1980 \mathrm{a})\end{array}$} & & & \multirow{2}{*}{$\sim 25-27$} & $\begin{array}{c}75 \pm 7 \text { and } 63 \pm 3 \text { ka from U/Th } \\
(\text { BRÜCKNER, 1980a) }\end{array}$ & LP & \multirow{2}{*}{$\begin{array}{l}0.22-0.33 \\
(\mathrm{E})^{* *}\end{array}$} \\
\hline & & & & & & $\begin{array}{c}110 \pm 10 \mathrm{ka} \text { from U/Th } \\
(\text { BRÜCKNER, 1980a) }\end{array}$ & $\mathrm{CM}$ & \\
\hline \multirow[t]{2}{*}{5.3} & \multirow[t]{2}{*}{ San Basilio } & \multirow[t]{2}{*}{$\begin{array}{c}\text { CAPUTO et } \\
\text { alii }(2010)\end{array}$} & \multirow[t]{2}{*}{$\sim 60$} & \multirow[t]{2}{*}{$\sim 37$} & & $\begin{array}{c}99.4 \pm 9.7 \mathrm{ka} \text { from empirical relationship } \\
\text { between } \mathrm{D} / \mathrm{L} \text { ratios and } \mathrm{U} / \mathrm{Th} \text { absolute } \\
\text { ages of BELLUOMINI et alii (2002) applied } \\
\text { to } \mathrm{D} / \mathrm{L} \text { ratio of } 0.43 \pm 0.03 \text { (DAI PRA \& } \\
\text { HEARTY, 1992) } \\
\end{array}$ & PR & \multirow[t]{2}{*}{$\begin{array}{l}0.7-0.8(W) \\
0.4-0.6(C)\end{array}$} \\
\hline & & & & & & $\begin{array}{c}\text { Between } 83.7 \pm 7.4 \text { and } 69.5 \pm 7.9 \text { from } \\
\text { OSL (ZANDER et alii (2006). Correction } \\
\text { with stratigraphic position }\end{array}$ & STII & \\
\hline \multirow{4}{*}{5.5} & $\begin{array}{l}\text { Terrazzo di } \\
\text { Ponte del Re }\end{array}$ & $\begin{array}{c}\text { BoENZI et } \\
\text { alii (1985) }\end{array}$ & & $\sim 45$ & & Senegalese fauna & PR & $0.31^{*}$ \\
\hline & $\begin{array}{l}\text { Terrazzo di } \\
\text { Ponte del Re }\end{array}$ & $\begin{array}{c}\text { DAI PRA } \\
\& \text { HEARTY } \\
(1992) \\
\end{array}$ & & $\sim 35$ & & $\begin{array}{c}\mathrm{D} / \mathrm{L} \text { ratio of } 0.43 \pm 0.03 \text { corresponding to } \\
\text { Aminozone E, associated with MIS } 5.5 \\
\text { (HEARTY et alii, 1986) }\end{array}$ & PR & $0.23^{*}$ \\
\hline & Marconia & $\begin{array}{l}\text { CAPUTO et } \\
\text { alii }(2010)\end{array}$ & $\sim 85$ & $\sim 50$ & & & & $\begin{array}{l}0.6-0.7(\mathrm{~W}) \\
0.2-0.4(\mathrm{C}) \\
\end{array}$ \\
\hline & $\mathrm{T} 2 / \mathrm{T}^{(1)}$ & $\begin{array}{c}\text { BRÜCKNER } \\
(1980 \mathrm{a})\end{array}$ & $\sim 80-85$ & $\sim 75-80$ & $\sim 50$ & & & $\begin{array}{c}0.59-0.63(\mathrm{~W}) \\
0.55-0.59(\mathrm{C}) \\
0.35(\mathrm{E})^{*} \\
\end{array}$ \\
\hline 7.1 & Bernalda & $\begin{array}{l}\text { CAPUTO et } \\
\text { alii }(2010)\end{array}$ & $\sim 140$ & $\sim 80(?)$ & & & & $\begin{array}{c}0.7-0.8(\mathrm{~W}) \\
0.4-0.5(\mathrm{C}) \\
\end{array}$ \\
\hline $7.1(?)$ & $\mathrm{T} 4 / 5(?)$ & $\begin{array}{l}\text { BRÜCKNER } \\
(1980 a)\end{array}$ & $\sim 130-140$ & $\sim 100$ & $\sim 90-100$ & & & $\begin{array}{c}0.69-0.79(\mathrm{~W}) \\
0.54-0.58(\mathrm{C}) \\
0.50-0.58 \\
(\mathrm{E})^{* * *}\end{array}$ \\
\hline \multirow{4}{*}{$\begin{array}{c}\text { Post- } \\
\text { Calabrian } \\
\text { (?) }\end{array}$} & T5 & $\begin{array}{l}\text { BoenzI et } \\
\text { alii }(1977)\end{array}$ & $\sim 125$ & $\begin{array}{l}\sim 110- \\
125\end{array}$ & & & & \\
\hline & T6 & $\begin{array}{l}\text { BoenzI et } \\
\text { alii (1977) }\end{array}$ & $\sim 85-90$ & $\sim 70$ & & & & \\
\hline & $\mathrm{T} 7$ & $\begin{array}{l}\text { BoENZI et } \\
\text { alii (1977) }\end{array}$ & $\sim 20-25$ & $\sim 30$ & & & & \\
\hline & $\mathrm{T} 8$ & $\begin{array}{l}\text { BoEnZI et } \\
\text { alii }(1977)\end{array}$ & $\sim 10-15$ & & & & & \\
\hline
\end{tabular}

* inferred by assuming an age of $125 \mathrm{ka}$ and a sea level at $+6 \mathrm{~m}$; ** inferred by assuming an age of $73 \div 87 \mathrm{ka}$ and a sea level at $+3 \div 6 \mathrm{~m}(\mathrm{CoyNE}$ et alii, 2007); *** inferred by assigning the MIS 7.1 to T3/4 terrace and assuming an age of $189.7 \div 201.5 \mathrm{ka}$ (DuTTON et alii, 2009) and a sea level at Ca. $-10 \mathrm{~m}$ (WAELBROEK et alii, 2002).

(1) In our study area, BRÜCKNER (1980a) can not distinguish the limit between T2 and T3 terraces, and consequently reports a single terrace called T2/T3; therefore, these data come from our interpretation that in the study area the T2/T3 is a single T2 terrace referable to the MIS 5.5 .

LP = La Petrulla; SN = Piano San Nicola; LM = La Maddalena; ST1 = San Teodoro I; CM = Cozzo Marziotta; PR = Ponte del Re; ST2 = San Teodoro II. 


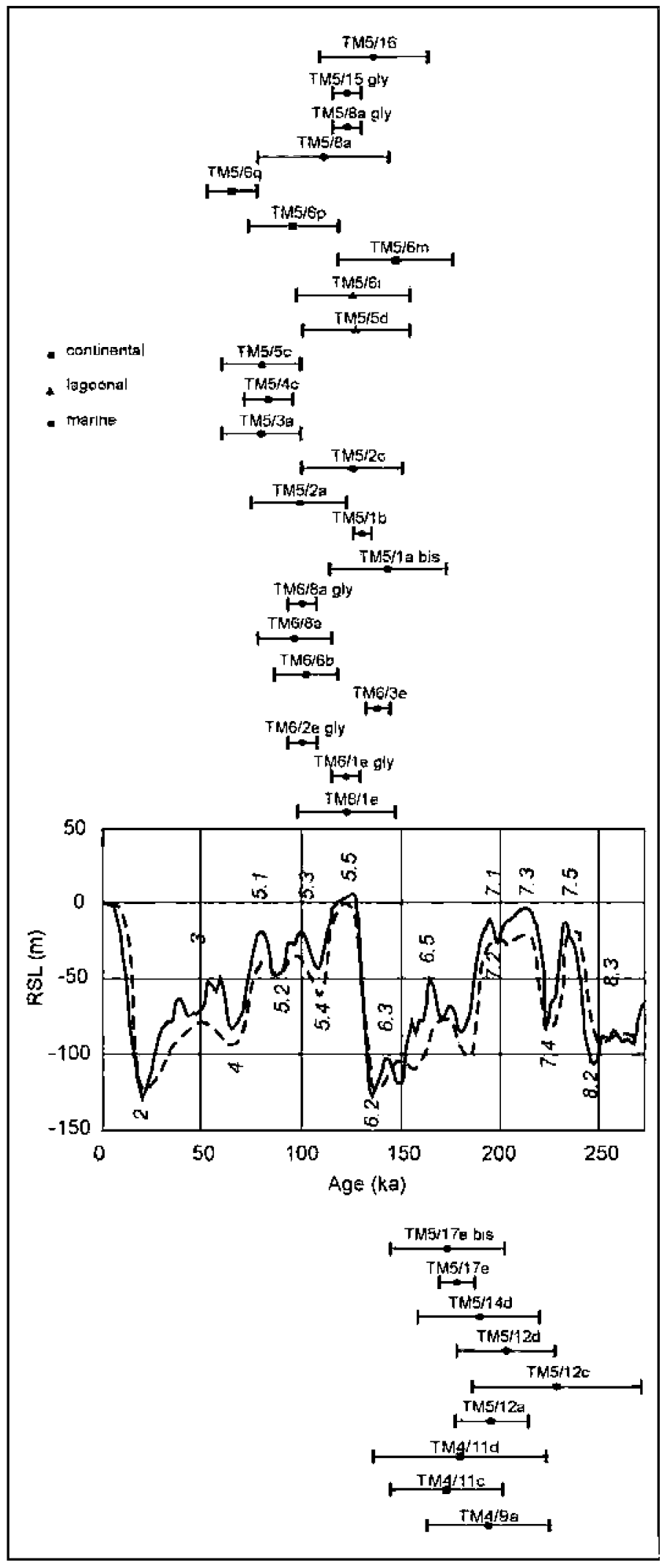

Fig. 2 - Schematic geomorphological map. The terrace deposits, the givoni, and the studied and literature sites are presented.

could explain certain high standard deviations of some ages obtained here through AAR.

\section{DATA AND RESULTS}

DATING

After rejecting a number of samples based on the criteria described in the Methods section, 28 beds (Tabs. 2 and 3) from 19 sites (Fig. 2) were used to determine the ages. The numerical AAR ages (Tab. 2) are clustered in two groups centred on MIS 7 (except the MIS 7.5) and MIS 5 (Fig. 3) in the reference isotopic curves (CHAPPELl et alii, 1996, WAELBROECK et alii, 2002; BinTANJA et alii, 2005).

The five beds that were dated using Glycymeris shells yielded $\mathrm{D}$-aIle/L-Ile values (Tab. 3) consistent with those of MIS 5.5 and MIS 5.3 from marine terrace deposits scattered around the Mediterranean (BELLuomini et alii, 2002; CAldara et alii, 2003; Torres et alii, 2013).

\section{STRATIGRAPHY}

\section{General framework}

Above a wave-cut platform incised into the substrate (mainly the ASP unit), terrace deposits made of calcareous to siliciclastic, sandy and gravelly sediments have accumulated, reaching up to ca. $20 \mathrm{~m}$ thick. In the remainder of the text, we distinguish the siliciclastic component derived from the Apennines and the carbonate component derived from the Murge highland.

All terraces generally display a sub-planar and slightly seaward sloping geometry $\left(3-5^{\circ}\right)$ and are incised by the main rivers and secondary tributaries that form the stream network of the area (Fig. 2).

\section{MIS 7 Terrace deposits}

In this section, we describe the most representative stratigraphic sections of the MIS 7 terrace deposits.

\section{TM4/11 Masseria Speziale}

The Masseria Speziale stratigraphic section (Fig. 4), is exposed east of the homonymous farm; the outcrop consists of an artificial section created following the demolition of a large area, which left an isolated hill with a farm home on its top.

From the bottom of the sequence upward, we observed 2.3 metres of light beige, fine bioturbated sands with rare small pebbles that gradually increase upwards. In this part, the macrofauna is poor and is represented by Anomia patelliformis and Pecten sp. fragments. The microfaunal content is dominated by benthic foraminifera and ostracods.

The second unit, ca. $24 \mathrm{~cm}$ thick, is composed of very light beige, fine sand marked at the base by a $2-\mathrm{cm}$ thick layer of small pebbles; the macrofauna is represented by Corbicula fluminalis, Theodoxus fluviatilis, Hydrobiidae, Pseudamnicola sp., Valvata piscinalis, and Cernuella sp. The microfaunal content is dominated by ostracods and Characeae.

The succession continues with a third unit, ca. $70 \mathrm{~cm}$ thick, composed of light beige silt that ishighly bioturbated; the macrofaunal content is represented by Bithynia sp. and $T$. fluviatilis, whereas the microfaunal content is represented by ostracods. 
Aspartic acid (Asp) and glutamic acid (Glu) D/L values in ostracod valves of the sites with their corresponding ages; for the provenance of the samples, see the geological map (Fig. 2) and/or sections (Figs. 4-9). The acronyms TM5/17e and TM5/17e bis refer to a same bed from which two samples were taken. ${ }^{*}$ ) samples rejected because Asp and Glu D/L values fall outside the $2 \sigma$ range of the group (cf. HEArTy et alii, 2004; KosniK \& KaufMaN, 2008); (**) samples rejected due to a standard deviation greater or equal to $25 \%$ of the mean value.

\begin{tabular}{|c|c|c|c|c|c|c|}
\hline Bed & Location & $\begin{array}{c}\text { Analytical } \\
\text { samples }\end{array}$ & D/L Asp & D/L Glu & Age (ky) & MIS \\
\hline TM4/9a & Mass Gaudella & 5 & $0.452 \pm 0.009$ & $0.166 \pm 0.013$ & $196.0 \pm 31.2$ & 7 \\
\hline TM4/11a & $\begin{array}{c}\text { Casa su Isola- Mass. } \\
\text { speziale }\end{array}$ & 2 & $0.444 \pm 0.083$ & $0.202 \pm 0.082$ & $\begin{array}{c}221.2 \pm 84.9 \\
(* *)\end{array}$ & \\
\hline $\mathrm{TM} 4 / 11 \mathrm{c}$ & $\begin{array}{c}\text { Casa su Isola- Mass. } \\
\text { speziale }\end{array}$ & 5 & $0.409 \pm 0.039$ & $0.169 \pm 0.022$ & $175.4 \pm 28.5$ & 7 \\
\hline TM4/11d & $\begin{array}{c}\text { Casa su Isola- Mass. } \\
\text { speziale }\end{array}$ & 5 & $0.403 \pm 0.055$ & $0.176 \pm 0.033$ & $181.6 \pm 44.1$ & 7 \\
\hline TM5/12a & Mass. Stoccatarda high & 3 & $0.437 \pm 0.013$ & $0.185 \pm 0.010$ & $196.6 \pm 18.5$ & 7 \\
\hline TM5/12b & Mass. Stoccatarda high & 5 & $0.432 \pm 0.040$ & $0.173 \pm 0.035$ & $194.6 \pm 52.2(* *)$ & \\
\hline TM5/12c & Mass. Stoccatarda high & 5 & $0.465 \pm 0.018$ & $0.204 \pm 0.029$ & $229.7 \pm 42,8$ & 7 \\
\hline TM5/12d & Mass. Stoccatarda high & 4 & $0.452 \pm 0.008$ & $0.179 \pm 0.009$ & $204.2 \pm 24.7$ & 7 \\
\hline TM5/14d & Mass. Stoccatarda high & 5 & $0.430 \pm 0.024$ & $0.179 \pm 0.015$ & $190.3 \pm 30.7$ & 7 \\
\hline TM5/17e & Mass. Stoccatarda high & 4 & $0.423 \pm 0.002$ & $0.169 \pm 0.003$ & $179.3 \pm 8.7$ & 7 \\
\hline TM5/17e bis & Mass. Stoccatarda high & 2 & $0.427 \pm 0.014$ & $0.157 \pm 0.017$ & $174.3 \pm 29.2$ & 7 \\
\hline TM5/1a bis & Mass D'Anela & 5 & $0.374 \pm 0.044$ & $0.150 \pm 0.020$ & $144.9 \pm 29.6$ & 5 \\
\hline TM5/1b & Mass D'Anela & 2 & 0.367 & 0.123 & $131.9 \pm 4.6$ & 5 \\
\hline TM5/2a & canale Palagiano & 5 & $0.346 \pm 0.020$ & $0.105 \pm 0.010$ & $99.8 \pm 24.2$ & 5 \\
\hline TM $5 / 2 \mathrm{c}$ & canale Palagiano & 3 & 0.341 & 0.128 & $126.9 \pm 25.8$ & 5 \\
\hline TM5/3a & canale Palagiano & 5 & $0.371 \pm 0.014$ & $0.091 \pm 0.020$ & $80.8 \pm 20.2$ & 5 \\
\hline TM5/4a & canale Palagiano & 5 & $0.367 \pm 0.042$ & $0.140 \pm 0.042$ & $135.5 \pm 49.8(* *)$ & \\
\hline TM $5 / 4 \mathrm{c}$ & canale Palagiano & 1 & 0.312 & 0.066 & $84.2 \pm 12.2$ & 5 \\
\hline TM5/5c & canale Palagiano & 2 & 0.289 & 0.109 & $80.8 \pm 20.0$ & 5 \\
\hline TM5/5d & canale Palagiano & 5 & $0.321 \pm 0.020$ & $0.114 \pm 0.033$ & $128.6 \pm 27.1$ & 5 \\
\hline TM5/5e & canale Palagiano & 5 & $0.386 \pm 0.021$ & $0.169 \pm 0.023$ & $(*)$ & \\
\hline TM5/5f & canale Palagiano & 5 & $0.316 \pm 0.061$ & $0.124 \pm 0.015$ & $114.1 \pm 46.1\left(^{* *}\right)$ & \\
\hline TM5/6a & Fontana del Fico & 3 & $0.397 \pm 0.100$ & $0.158 \pm 0.097$ & $160.1 \pm 100.5(* *)$ & \\
\hline TM5/6f & Fontana del Fico & 5 & $0.359 \pm 0.028$ & $0.100 \pm 0.030$ & $104.4 \pm 47.4(* *)$ & \\
\hline TM5/6g & Fontana del Fico & 5 & $0.366 \pm 0.016$ & $0.100 \pm 0.010$ & $105.3 \pm 34.6(* *)$ & \\
\hline TM5/6h & Fontana del Fico & 5 & $0.347 \pm 0.024$ & $0.096 \pm 0.015$ & $92.6 \pm 35.0(* *)$ & \\
\hline TM5/6i & Fontana del Fico & 5 & $0.376 \pm 0.020$ & $0.117 \pm 0.014$ & $127.1 \pm 29.0$ & 5 \\
\hline TM5/6l & Fontana del Fico & 5 & $0.368 \pm 0.009$ & $0.105 \pm 0.012$ & $111.3 \pm 32.9(* *)$ & \\
\hline TM5/6m & Fontana del Fico & 5 & $0.386 \pm 0.013$ & $0.136 \pm 0.028$ & $148.7 \pm 29.1$ & 5 \\
\hline TM5/6n & Fontana del Fico & 5 & $0.341 \pm 0.030$ & $0.093 \pm 0.015$ & $86.8 \pm 35.6(* *)$ & \\
\hline TM5/60 & Fontana del Fico & 5 & $0.315 \pm 0.062$ & $0.106 \pm 0.035$ & $93.0 \pm 54.0(* *)$ & \\
\hline TM5/6p & Fontana del Fico & 5 & $0.307 \pm 0.010$ & $0.116 \pm 0.008$ & $96.6 \pm 22.9$ & 5 \\
\hline TM5/6q & Fontana del Fico & 5 & $0.293 \pm 0.011$ & $0.093 \pm 0.010$ & $65.7 \pm 12.6$ & 5 \\
\hline TM5/8c & $\begin{array}{l}\text { Near Mass. Sant'Andrea } \\
\text { Grande }\end{array}$ & 5 & $0.384 \pm 0.075$ & $0.144 \pm 0.065$ & $(*)$ & \\
\hline TM5/8a & $\begin{array}{c}\text { Near Mass. Sant'Andrea } \\
\text { Grande }\end{array}$ & 5 & $0336 . \pm 0.018$ & $0.132 \pm 0.034$ & $111.4 \pm 33.2$ & 5 \\
\hline TM5/16a & Mass. Sant'Andrea Grande & 3 & $0.373 \pm 0.019$ & $0.135 \pm 0.021$ & $137.0 \pm 27.2$ & 5 \\
\hline TM6/1b & Ponte del Re & 3 & $0.398 \pm 0.070$ & $0.154 \pm 0.054$ & $166.8 \pm 63.4(* *)$ & \\
\hline TM6/1e & Ponte del $\operatorname{Re}$ & 4 & $0.342 \pm 0.015$ & $0.140 \pm 0.024$ & $123.7 \pm 24.8$ & 5 \\
\hline TM6/2d & Mass. Perrone & 2 & 0.418 & 0.162 & $(*)$ & \\
\hline TM6/8a & Mass. Perrone & 2 & $0.318 \pm 0.000$ & $0.113 \pm 0.008$ & $97.3 \pm 18.9$ & 5 \\
\hline TM6/3b & Mass. Simeone & 3 & $0.308 \pm 0.024$ & $0.099 \pm 0.025$ & $79.8 \pm 31.4(* *)$ & \\
\hline TM6/3c & Mass. Simeone & 2 & 0.409 & 0.159 & $(*)$ & \\
\hline TM6/3e & Mass. Simeone & 1 & 0.367 & 0.147 & $139.6 \pm 6.3$ & 5 \\
\hline TM6/6b & Cave Sarim & 2 & $0.318 \pm 0.002$ & $0.122 \pm 0.009$ & $102 \pm 16$ & 5 \\
\hline
\end{tabular}


Isoleucine epimerisation values (D-aIle/L-Ile) in Glycymeris shells of the samples studied with their corresponding ages; for the provenance of the samples see the geological map (Fig. 2) and/or sections (figs. 4-9). The acronyms TM5/8a gly, TM6/1e gly, and TM6/8a gly refer to a same bed of TM5/8a, TM6/1e, and TM6/8a (tab 2), but with Glycymeris shells samples.

\begin{tabular}{|c|c|c|c|c|}
\hline Bed & Area & $\begin{array}{c}\text { Analytical } \\
\text { samples }\end{array}$ & D-aIle/L-Ile & Age (ky) \\
\hline TM5/8a gly & Near Mass. Sant'Andrea Grande & 5 & $0.462 \pm 0.032$ & MIS 5.5 (according to Torres et al., 2013) \\
\hline TM5/15 gly & Near Mass D'Anela & 6 & $0.490 \pm 0.026$ & MIS 5.5 (according to Torres et al., 2013) \\
\hline TM6/1e gly & Ponte del Re & 4 & $0.480 \pm 0.056$ & MIS5.5 (according to Torres et al., 2013) \\
\hline TM6/2e gly & Mass. Perrone & 2 & $0.436 \pm 0.048$ & MIS 5.3 (according to Belluomini et al., 2002) \\
\hline TM6/8a gly & Mass. Perrone & 6 & $0.427 \pm 0.026$ & MIS 5.3 (according to Belluomini et al., 2002) \\
\hline
\end{tabular}

The Masseria Speziale succession reveals an evolution from marine deposition, probably infralittoral, into continental deposits dominated first by running freshwater, then more standing water.

Based on AAR dating of the ostracod shells, the beds in this section yielded two valid ages: $175.4 \pm 28.5 \mathrm{ka}$ and $181.6 \pm 44.1 \mathrm{ka}$.

\section{TM4/9 Masseria Gaudella}

The Masseria Gaudella stratigraphic section (Fig. 5) is naturally exposed west of the homonymous farm.

Starting from the bottom and moving up, there is 45 $\mathrm{cm}$ of microconglomerate that gradually transitions into a microconglomerate with a clay matrix and then into grey clay with scattered micro-pebbles. In the upper part of this unit, the macrofaunal content consists of Theodoxus fluviatilis, ostracods and other reworked fossils.

In abrupt contact with the above-described unit, there is a second unit, which is $1.80 \mathrm{~m}$ thick; at the base, it is made of sub-centimetric gravels of an Apenninic source. These gravels, increase in size upwards and are characterised by coloured bands from black to brown to russet with a presence of concave erosional surfaces. Toward the top, the unit becomes generally finer, passing first into alternating coarse sand and gravel layers with horizontal lamination, and then into sand with sub-horizontal to undulating lamination.

In abrupt erosional contact with the above-described unit, the final unit consists of ca. $2.5 \mathrm{~m}$ of coarse reddish gravels, mainly of Murgian source.

The first two units of the Masseria Gaudella section indicate a continental/floodplain palaeoenvironment characterised by episodes of running water. The third unit is interpreted as an alluvial fan body, deposited by a stream that drained the Murge highlands.

The only bed from this section that yielded a valid age using the AAR method applied to the ostracod shells indicated an age of $196.0 \pm 31.2 \mathrm{ka}$ (Tab. 2).

\section{TM5/10-14 and TM5/17: Masseria Stoccatarda high}

A group of stratigraphic sections located near Masseria Stoccatarda is significant because it features a calcareous biohermal and biostromal dome that is rich in Cladocora caespitosa, calcareous algae and bryozoans, hereinafter referred to as the Masseria Stoccatarda high. In sections TM5/10, TM5/11, TM5/13, and TM5/14, only calcareous biohermal-biostromal deposits are exposed, whereas in section TM5/12 the organogenic calcareous deposits are overlain by siliciclastic sands.

The most significant section is section TM5/17 (Fig. 6), which exposes more than $5 \mathrm{~m}$ of terrace deposits. The lowermost unit, approximately $1 \mathrm{~m}$ thick, consists of sandy sediments that fine upward and contain clayey and arenaceous beds. In its upper part, lenses of fine bioclastic sands are present. The macrofauna is poor and represented mostly by fragments of Pecten sp. The microfaunal content is represented by planktonic and benthic foraminifera and rare ostracods. The second unit in the succession is approximately $4 \mathrm{~m}$ thick and overlies the lowermost unit along an abrupt erosional contact, and it consists of massive cemented biostromal-biohermal limestone composed of calcareous algae, bryozoans, serpulids, echinoids, Cladocora caespitosa, and bioclastic fragments. The macrofauna consist mostly of Megathyris detruncata, Crania anomala, Argyrotheca cuneata, Chlamys multistriata, C. varia, Limaria tuberculata, Anomia sp., Bolma rugosa and Cerithiopsis tubercularis. The microfaunal content is represented by benthic foraminifera and rare ostracods.

The succession continues with a third transgressive unit composed of grey-brown siliciclastic sandstones that alternate with loose sands. No macrofauna was observed. Horizontal lamination is evident and appears to fill erosion marks and Lithodomus holes in the surface of the underlying limestone unit. Based on AAR dating of the ostracods shells, the Masseria Stoccatarda high yielded ages between a minimum of $174.3 \pm 29.2 \mathrm{ka}$ and a maximum of $229.7 \pm 42.8 \mathrm{ka}$ (Tab. 2). The third unit does not contain dateable fauna, but the evidence of its transgression above the MIS 7 substrate indicates that it represents another terrace deposit younger than MIS 7.

\section{MIS 5 TERRACE DEPOSITS}

In this section, we describe the most representative stratigraphic sections of the MIS 5 terrace deposits.

\section{TM5/2-5 Canale Palagiano}

The Canale Palagiano stratigraphic section (Fig. 7) is exposed along the walls of a canal east of the city of Palagiano and represents a composite of 4 partial sections (TM5/2-5). Because of the low height of the canal walls (max $4 \mathrm{~m}$ ) and the subhorizontal bedding of the deposits, this section is not as significant for its vertical variations as it is for its lateral variations, which can be observed roughly 


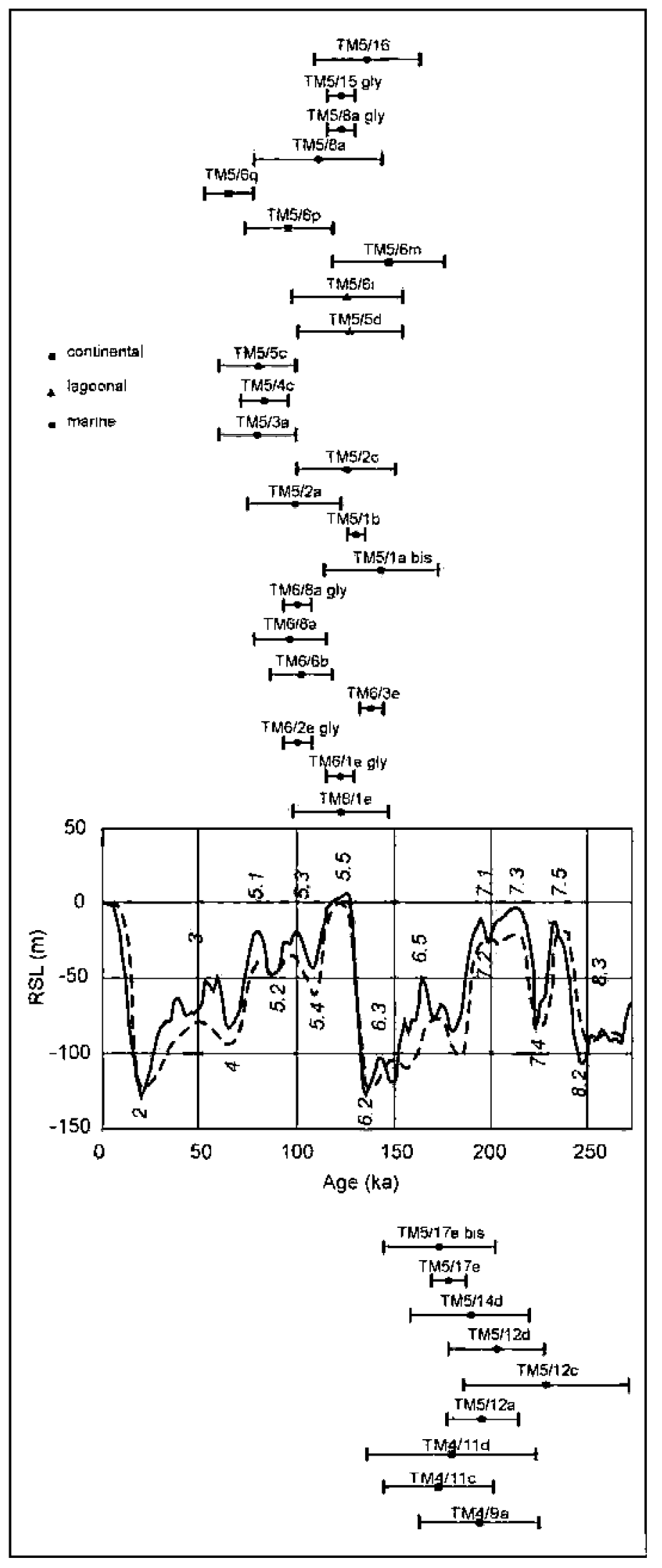

Fig. 3 - Numerical ages obtained with the AAR dating method applied to ostracod shells and isotope stages assigned to samples based on the isoleucine epimerisation method obtained for Glycymeris sp. Each age reports the mean value, its standard deviation, and the palaeoenvironment. The ages are plotted on sea level curves (RSL): continuous line (WAELBRoek et alii, 2002) and dotted line (BINTANJA et alii, 2005).

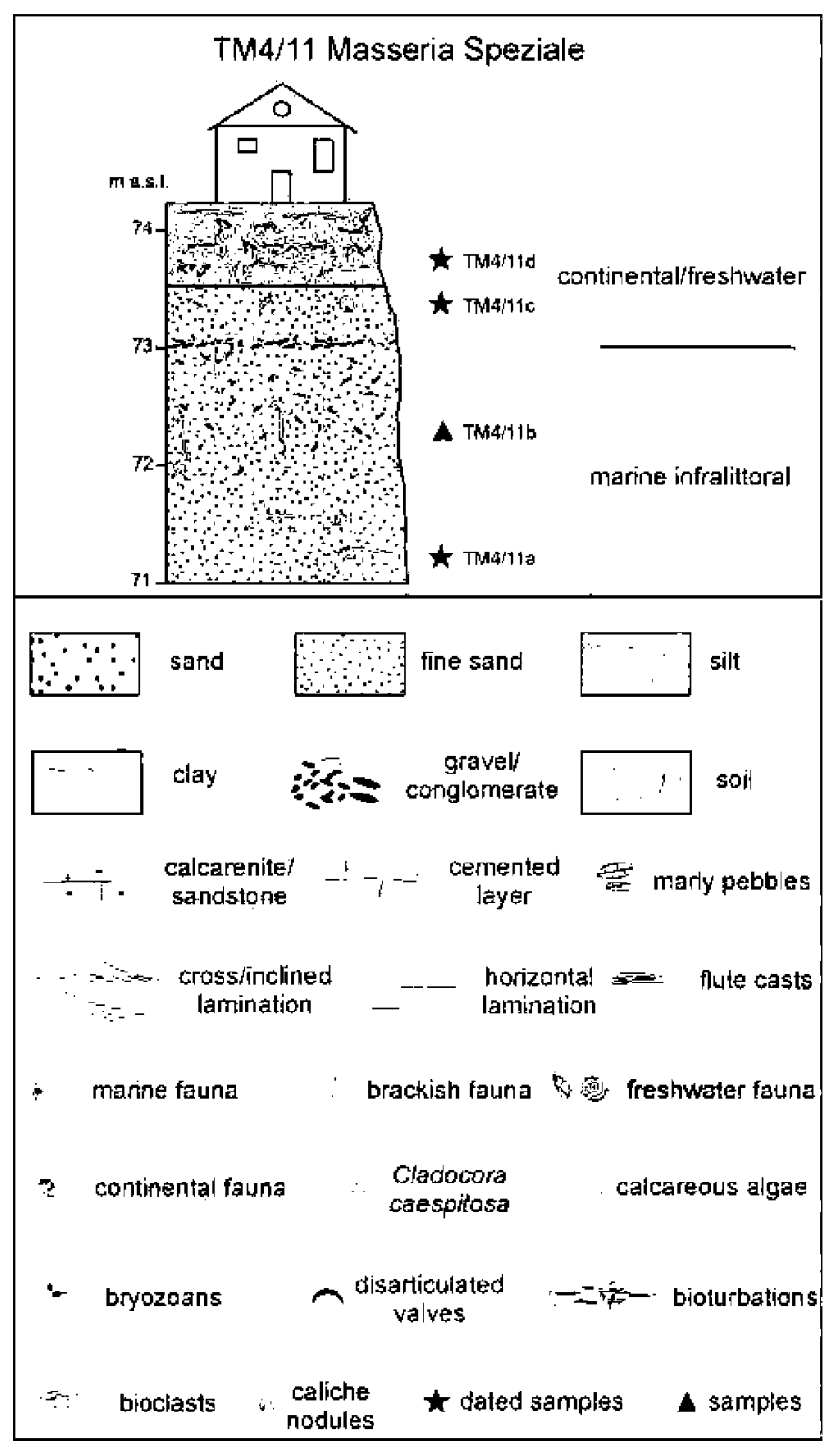

Fig. 4 - Stratigraphic column of the TM4/11 Masseria Speziale location. The legend reported is also valid for figg. 5 to 12 . Regarding the gravel/conglomerate symbol, the white filling indicates a murgian source, whereas the black filling indicates an Apenninic source. For all the following figures: 1) $\mathrm{m}$ a.s.l. = elevations above sea level; 2) ASP = argille subappennine unit; 3 ) SFBC = fine well-sorted sand biocoenosis; 4) LEE = euryaline and eurytherm lagoon biocoenosis; 5) $\mathrm{AP}=$ photophilous algae biocoenosis; 6) VTC = circalittoral terrigenous mud biocoenosis.

from south to north. In general, starting in the south, medium-coarse, beige to brownish, partially cemented, mixed calcareous-siliciclastic sands can be observed. The calcareous component consists mostly of molluse shell remnants that are concentrated in centimetre-thick beds. This deposit is characterised by a generally gentle dip to the south with cross-bedding at both high and low angles.

The sands gradually grade into a massive central body composed of medium-coarse mixed calcareoussiliciclastic sands with scattered centimetre- to decimetrescale pebbles of Apenninic source. On the south side of the body, these pebbles are concentrated in beds that 


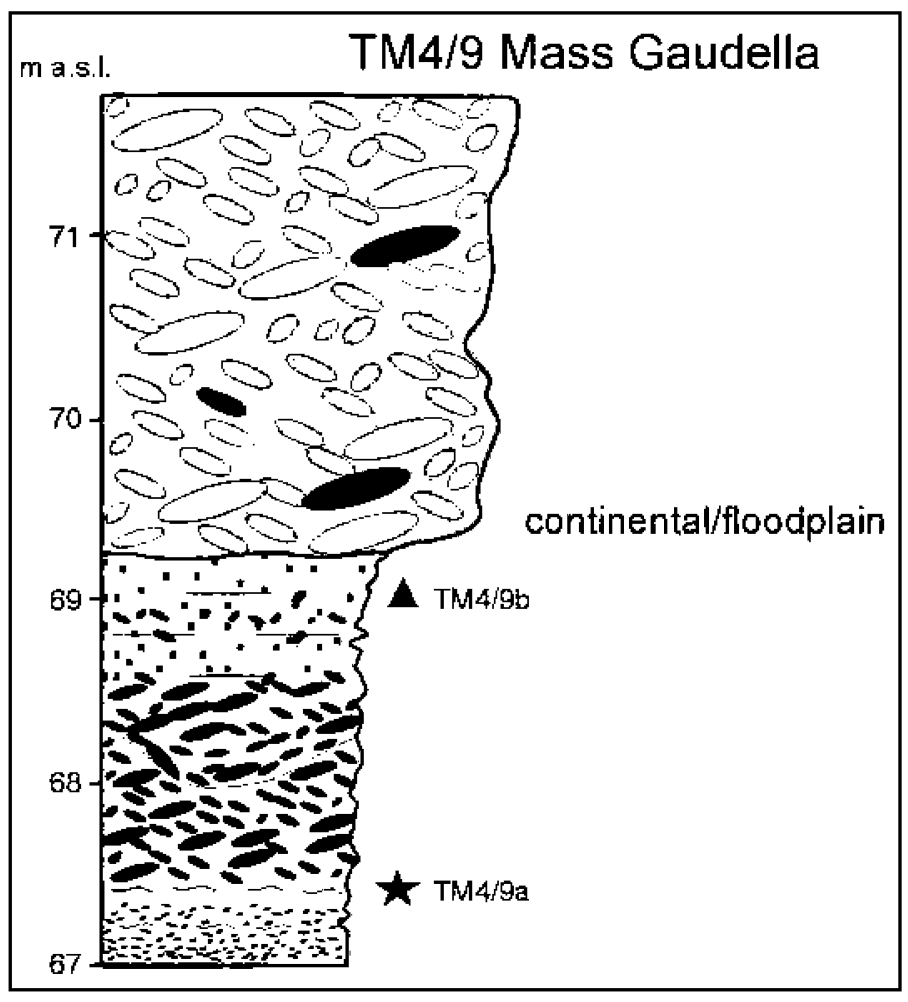

Fig. 5 - Stratigraphic column of the TM4/9 Masseria Gaudella location. For symbols and acronyms, see the legend and caption in Fig. 4.

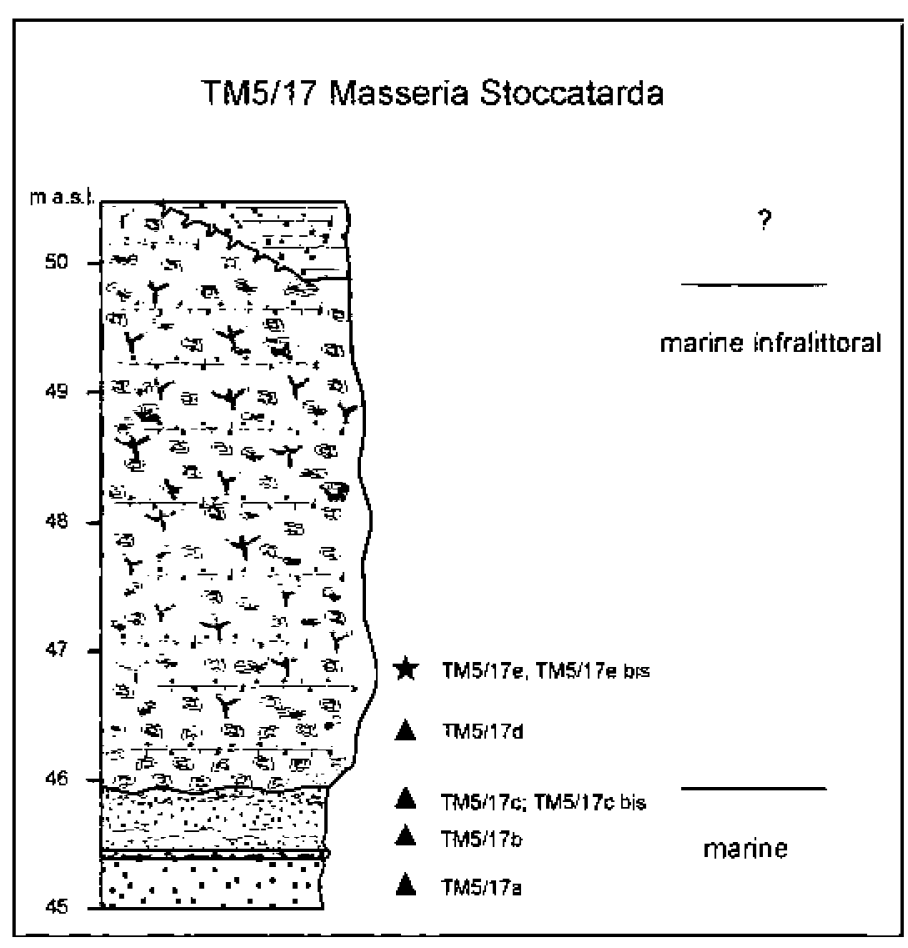

Fig. 6 - Stratigraphic column of the TM5/17 site, in the Masseria Stoccatarda high. For symbols and acronyms, see the legend and caption in Fig. 4.

increase in grain size downward, dipping to the south. The macrofauna is generally poor and includes Aequipecten opercularis, Chlamys varia, Anomia sp., bryozoans and molds of Veneridae, Glycymeris sp., Pitar rudis, Lucinella divaricata, Parvicardium sp., Bittium reticulatum, Monophorus perversus, Cerithiopsis tubercularis, and Retusa truncatula. The microfaunal content is dominated by benthic foraminifera, rare planktonic foraminifera and ostracods.

To the north, light beige calcareous-siliciclastic fine sands overlie the massive main body, and the lowermost beds are rich in Hydrobiidae, Cerastoderma glaucum and Abra segmentum, which are replaced upwards by Ovatella myosotis and Throcoidea pyramidata and other terrestrial gastropods. Over the light beige fine sands, a thin layer of pink silt rich in Planorbis planorbis, Hydrobiidae and subordinately Limnaea peregra, L. palustris, and Bithynia tentaculata is observed.

The palaeoenvironment recorded by this outcrop was a coastal system that transitioned from south to north from marine infralittoral to backshore zones with lagoons and freshwater ponds.

Based on AAR dating of the ostracod shells, the beds in this section yielded ages between a minimum of $80.8 \pm 20.0$ $\mathrm{ka}$ and a maximum of $128.6 \pm 27.1 \mathrm{ka}$.

\section{TM5/6 Fontana del Fico}

The Fontana del Fico stratigraphic section (Fig. 8), which was previously described by Laviano \& PennetTa (1980), is a composite of two natural sections exposed on the slopes of the Lenne River Valley, approximately 4 $\mathrm{km}$ west of the city of Palagiano. Section I, which is the southernmost, exposes the lower part of the sequence, and section II, which is farther north, exposes the upper part.

Starting from the bottom and moving up, tawny fine bioturbated sands are, overlain by a level of calcareous algae in a matrix of sand and small pebbles. In this part, the macrofauna is rich and is represented by Anomia ephippium, Aequipecten opercularis, Hyalopecten similis, Pododesmus patelliformis, Ostrea edulis, Spondylus sp., and Ditrupa comea. The microfaunal content is dominated by planktonic foraminifera with lesser amounts of benthic foraminifera and ostracods.

This basal part is overlain by the terrace deposit along an erosional surface. The lowermost portion of this deposit consists of heterometric polygenic gravels, i.e., gravel of both Murgian and Apenninic sources. Upward fining is evident: first, the sandy matrix increases and the pebbles gradually decrease in number and size, followed by gradation of the deposit into reddish clays. In this part, the fossils are almost absent, except for the presence of small, indeterminate, pulmonate gastropods in the reddish clays. Next is a thick unit (ca. 2.5-3 m thick) that consists of alternating thin layers of clayey silt, silty clays and clays that are dark brown to light beige that contain scattered pebbles at the base. In this part, the macrofauna is rich and represented by Cerastoderma glaucum, Abra segmentum, Hydrobiidae, Mytilaster minimus, Venerupis sp., Lymnaea stagnalis, Armiger crista, Gyraulus albus, G. laevis, Bithynia tentaculata, and Hippeutis complanatus. Upward, the macrofaunal assemblage merges gradually with an assemblage represented by Hydrobiidae Armiger crista, Valvata piscinalis, Bithynia leachi, Physa acuta, Radix auricularia, Lymnaea stagnalis, L. peregra, Gyraulus albus, Acroloxus lacustris, and Ancylus fluviatilis. Ostracods and Characeae are also abundant. 


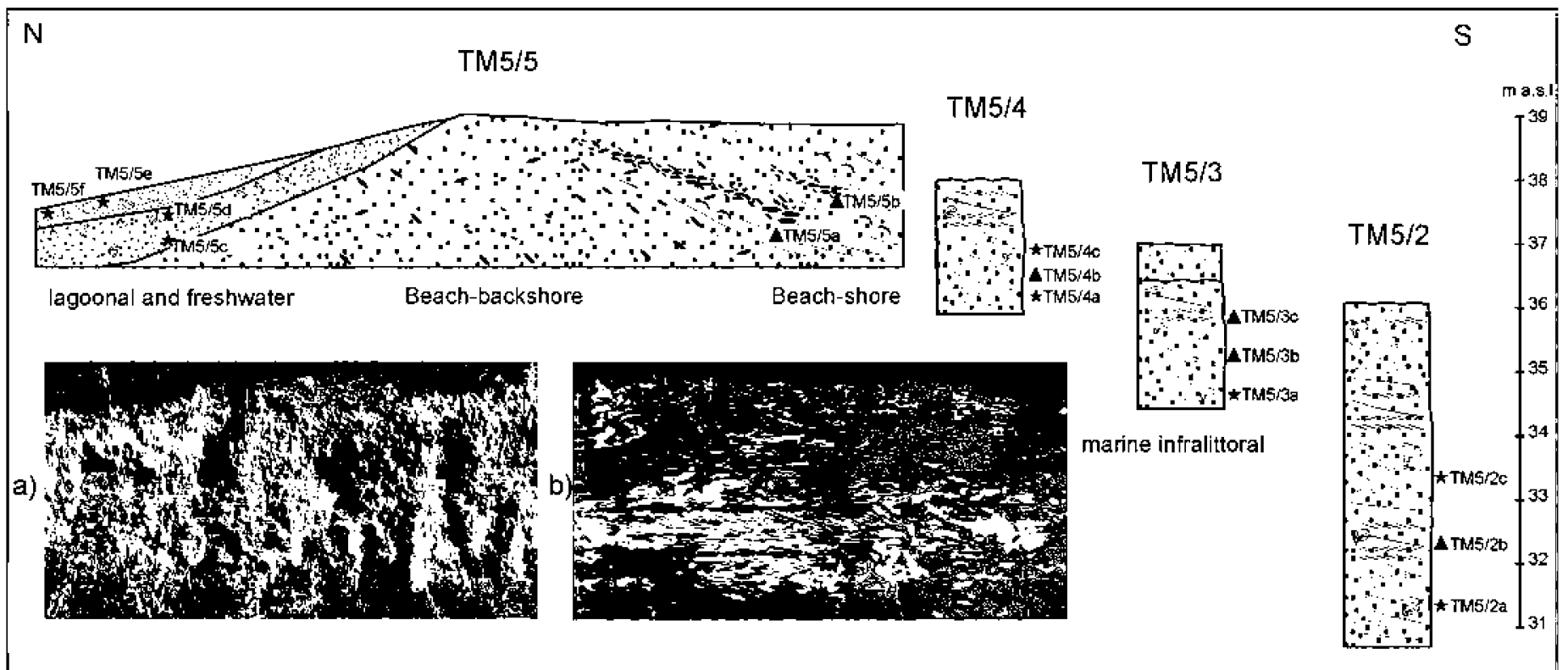

Fig. 7 - Stratigraphic sketch of the TM5/5 and columns of the TM5/2-4 sites, along a canal excavated to the east of the city of Palagiano. In particular, the photos show lagoonal and freshwater deposits (a) and cross bedding in the marine infralittoral sandstones (b). For symbols and acronyms, see the legend and caption in Fig. 4; note that for graphical reasons, the sandstone layers have not been reported.

The upper part of the Fontana del Fico section (outcrop II) begins with ca. $20 \mathrm{~cm}$ of brownish grey, clayey silt. This silt is overlain by ca. $30 \mathrm{~cm}$ of whitish sand that grades rapidly into light grey to whitish silt. The macrofauna is rich and represented by Hydrobiidae, Theodoxus fluviatilis, Bithynia leachi, B. tentaculata, Melanoides tuberculata, Radix auricularia, Lymnaea peregra, Planorbis planorbis, Gyraulus albus, Armiger crista, Acroloxus lacustris, Ancylus fluviatilis, Trochoidea pyramidata, Pupilla muscorum, and Clausiliidae sp. In addition, ostracods and Characeae are abundant. The uppermost layer in the section consists of a gravelly unit made of polygenic heterometric pebbles in a reddish clay matrix; lenses and beds of reddish clay are also present.

The Fontana del Fico succession shows an evolution from marine deposition, probably circalittoral (which we interpret as belonging to a previous terrace deposit that is currently not possible to identify), that was truncated by floodplain deposits. They grade into a lagoonal deposition with a faunal association that is representative of the euryaline and eurytherm lagoon biocoenosis (LEE sensu PÉrès, 1967) alternating with continental deposition. The continental depositional environment was dominated by streams based on the presence of Theodoxus fluviatilis, Radix auricularia and Ancylus fluviatilis or ponds with drought periods based on the presence of Gyraulus albus and Armiger crista. Upward, the macrofauna is represented by freshwater organisms in addition to Melanoides tuberculata. An uppermost conglomerate indicates a floodplain environment.

Based on AAR dating of the ostracod shells, this section yielded ages between a minimum of $65.7 \pm 12.6 \mathrm{ka}$ and a maximum of $148.7 \pm 29.1 \mathrm{ka}$ (Tab. 2).

\section{TM5/1 Masseria D'Anela}

The Masseria D'Anela stratigraphic section (Fig. 9), which was previously described by BoENzi et alii (1985), is exposed on the left side of the Lato River Valley, near Masseria D'Anela.

In the lower part of the section, the ASP is exposed, belonging to the Bradanic Trough cycle. Above is a terrace deposit that overlies an erosional contact, and its lowermost bed consists of approximately $3 \mathrm{~m}$ of greyish silts with light and dark intervals. The base is characterised by erosional pockets that are scoured into the ASP and are filled with coarse bioclastic sands. In this basal part of the terrace deposit, the macrofauna is rich and represented by Cerastoderma glaucum, Abra ovata, Loripes lacteus, Hydrobia stagnalis, Mytilaster lineatus; laterally, the macrofaunal assemblage becomes rich in Theodoxus fluviatilis, Valvata piscinalis, and Gyraulus albus. Ostracods and Characeae are also abundant.

This unit gradually grades upwards into fine-grained, brown-grey, cross-laminated siliciclastic sands with beds displaying flute casts. Upward, calcarenite layers alternate with siliciclastic sand layers. In this central part of the terrace deposit, the macrofauna is poor and represented by Aequipecten opercularis, Megathyris detruncata, Terebratulina retusa, Ostrea sp., bryozoans and echinoid fragments, and the microfauna is represented by benthic foraminifera and ostracods.

The upper part of the Masseria D'Anela section is made of approximately $4 \mathrm{~m}$ of an inclined-bedded calcarenite that grades upwards into fine, cross-bedded or inclinedbedded siliciclastic sand with polygenic heterometric pebbles at the base and horizontal bioturbated zones. Upward, the network of bioturbation (Thalassinoides) becomes denser and obliterates the sedimentary structures. The macrofauna is represented by Megathyris detruncata, bryozoans, Lucinella divaricata, Anomia ephippium, Pododesmus patelliformis, and several fragments of indeterminate bivalves. The microfauna is represented mostly by benthic foraminifera, with additional planktonic foraminifera, ostracods, and siliceous sponge. 


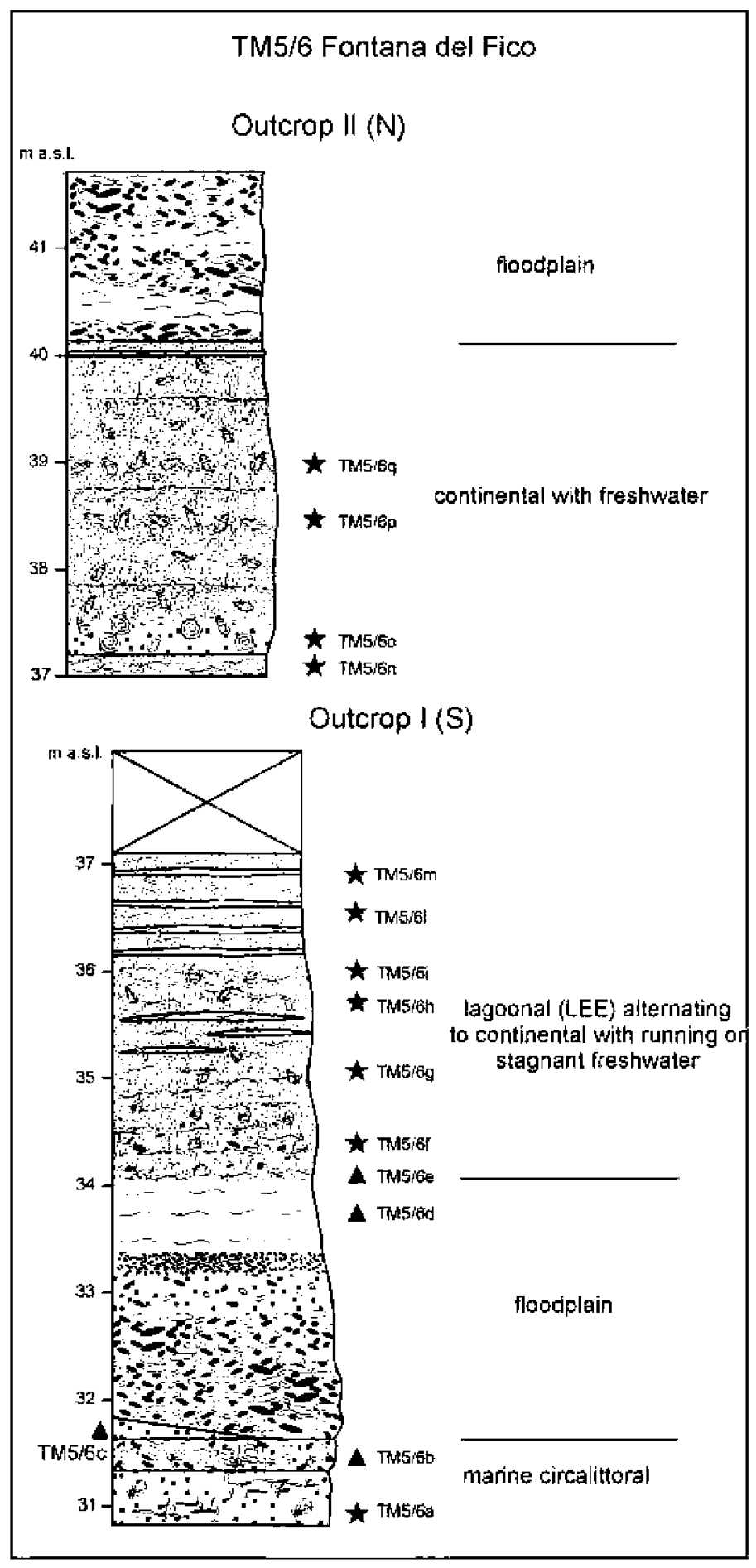

Fig. 8 - Stratigraphic column of the TM5/6 site at the Fontana del Fico locality. For symbols and acronyms, see the legend and caption in Fig. 4.

The palaeoenvironment of the terrace deposit of the Masseria D'Anela succession shows a transgressive trend that grades from a lagoonal environment with freshwater input to an infralittoral zone with a biocoenoses comparable to that of fine well-sorted sand (SFBC sensu PÉRÈs, 1967) dominated by currents to a deeper infralittoral environment. Based on AAR dating of the ostracod shells, this section yielded two valid ages: $131.9 \pm 4.6 \mathrm{ka}$ and a maxi- mum of $144.9 \pm 29.6 \mathrm{ka}$

\section{TM6/1 Ponte del Re}

The Ponte del Re site is located in the hinterland of Castellaneta Marina along the left side of the Lato River Valley. The classic Ponte del Re section, where the Senegalese fauna was identified (CALDARA, 1987), is now covered by colluvial deposits. We describe a new section (Fig. 10) located between sections 1 and 2 of BoEnzI et alii (1985).

In the lower part of the section, the ASP is exposed. It is overlain by terrace deposits with an erosional contact. The lowermost unit consists of conglomerate that is composed of marly pluridecimetric pebbles in a matrix of centimetric Apenninic pebbles. This unit is overlain by a bioconstructed biostromal-biohermal limestone with Cladocora caespitosa and scattered Apenninic centimetric pebbles. This limestone grades upwards into clayey sands and then into fine sands with flute casts. The lowest samples of the terrace deposits contain a rich macrofauna consisting of Cladocora caespitosa, Aequipecten opercularis, Chlamys varia, C. multistriata, C. pespelis, $C$. glabra, Spondylus gaederopus, Ostrea sp., Chama sp., Limaria sp., Bittium sp., Cerithiopsis sp., Megathyris detruncata, Argyrotheca cuneata, Crania anomala, cirripeds, shellfish, bryozoans and echinoid fragments. Higher in the section, the macrofauna is represented mostly by Glycymeris sp. The

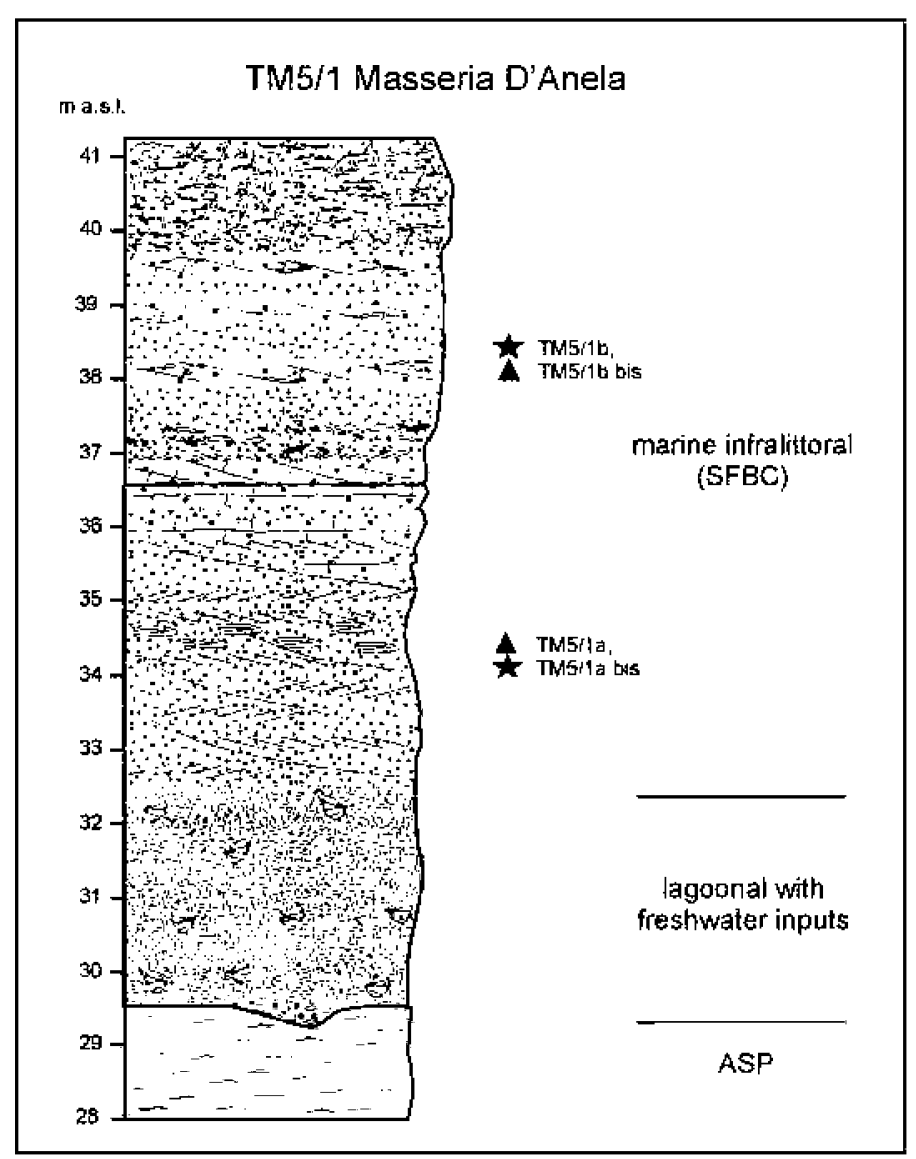

Fig. 9 - Stratigraphic column of the TM5/1 site, near Masseria D'Anela. For symbols and acronyms, see the legend and caption in Fig. 4. 
microfauna is represented mostly by benthic foraminifera but also includes planktonic foraminifera and ostracods. The uppermost part of the succession consists of a gravelly unit composed of Apenninic heterometric pebbles and contains moulds of Cerastoderma sp. (BoEnzi et alii, 1985).

The palaeoenvironment of the terrace deposit of the Ponte del Re succession displays a transgressive-regressive trend in which a marine infralittoral depositional environment characterised by hard substrata and a biocoenosis of photophilous algae (AP sensu PÉrès, 1967) grades into an infralittoral environment with soft substrata, probably a biocoenosis of well-sorted fine sands (SFBC sensu PÉRÈs, 1967) and then grades into a shore-beach environment.

Between the Lato River towards the surface of the terrace and ca. $800 \mathrm{~m} \mathrm{SE}$ of Ponte del Re, the contact between the Cladocora caespitosa bioherm and the underlying ASP is at an elevation of $15 \mathrm{~m}$ above sea level. This contact gradually rises in elevation until it joins at the outcrop at the Ponte del Re section, approximately $20 \mathrm{~m}$ above sea level. This structure suggests that the Cladocora caespitosa bioherm was deposited on a pre-existing ramp that dipped towards the S-SE and was incised into the ASP substrate.

The only bed from this section that yielded a valid age with the AAR method with ostracod shells indicated an age of $123.7 \pm 24.8 \mathrm{ka}$ (Tab. 2). In addition, in the same bed, a sample of Glycymeris sp. provided isoleucine epimerisation values (D-aIle/L-Ile ratios) of $0.480 \pm 0.056$ (Tab. 3 ).

\section{TM6/2 and TM6/8 Masseria Perrone}

The Masseria Perrone stratigraphic sections (of which only the TM6/2 section is shown in Fig. 11) are located in the near hinterland of Castellaneta Marina, along the right side of the Lato River Valley, at the foot of a spur on which the Masseria Perrone stands. The following description includes the units observed in both sections.

The lowermost unit is approximately $4 \mathrm{~m}$ thick, and the lowermost part of this unit consists of beige, fine sands with cemented bioturbations that are grouped in subhorizontal layers that become increasingly numerous and thicker upwards. Above, a ca. 40-cm thick bed with small bioturbations and well-developed horizontal lamination is observed. The uppermost part of this unit consists of beige, fine sands with abundant cemented bioturbations that are concentrated in thick irregular layers. In this lowermost unit, the macrofaunal community is rich and is represented at least by two stocks of species. An interesting stock is that of the species characteristic of heterogeneous association (PE sensu PICARD, 1965): Tellina distorta, Corbula gibba, Dentalium inaequicostatum, Nucula turgida, Nuculana pella, and Ditrupa cornea.; Secondarily, there is a stock of species characteristic of circalittoral terrigenous mud biocoenosis (VTC sensu PÉRÈs, 1967): Turritella communis and Acanthocardia paucicostata, as well as pelophilous Ova canaliferus.

The next higher unit is approximately $4 \mathrm{~m}$ thick and consists of massive beige, fine sands. The macrofauna is abundant in the lower part and consists of stocks of species characteristic of heterogeneous association (PE sensu Picard, 1965): Corbula gibba, Ditrupa cornea, Nuculanapella, Tellina distorta, and Dentalium inaequicostatum, with additional mixtophilous speciesincluding Timoclea ovata and Plagiocardium papillosum. Secondarily, there is a stock of species characteristic of circalittoral terrigenous mud biocoenosis (VTC sensu PÉRÈs, 1967): Turritella communis

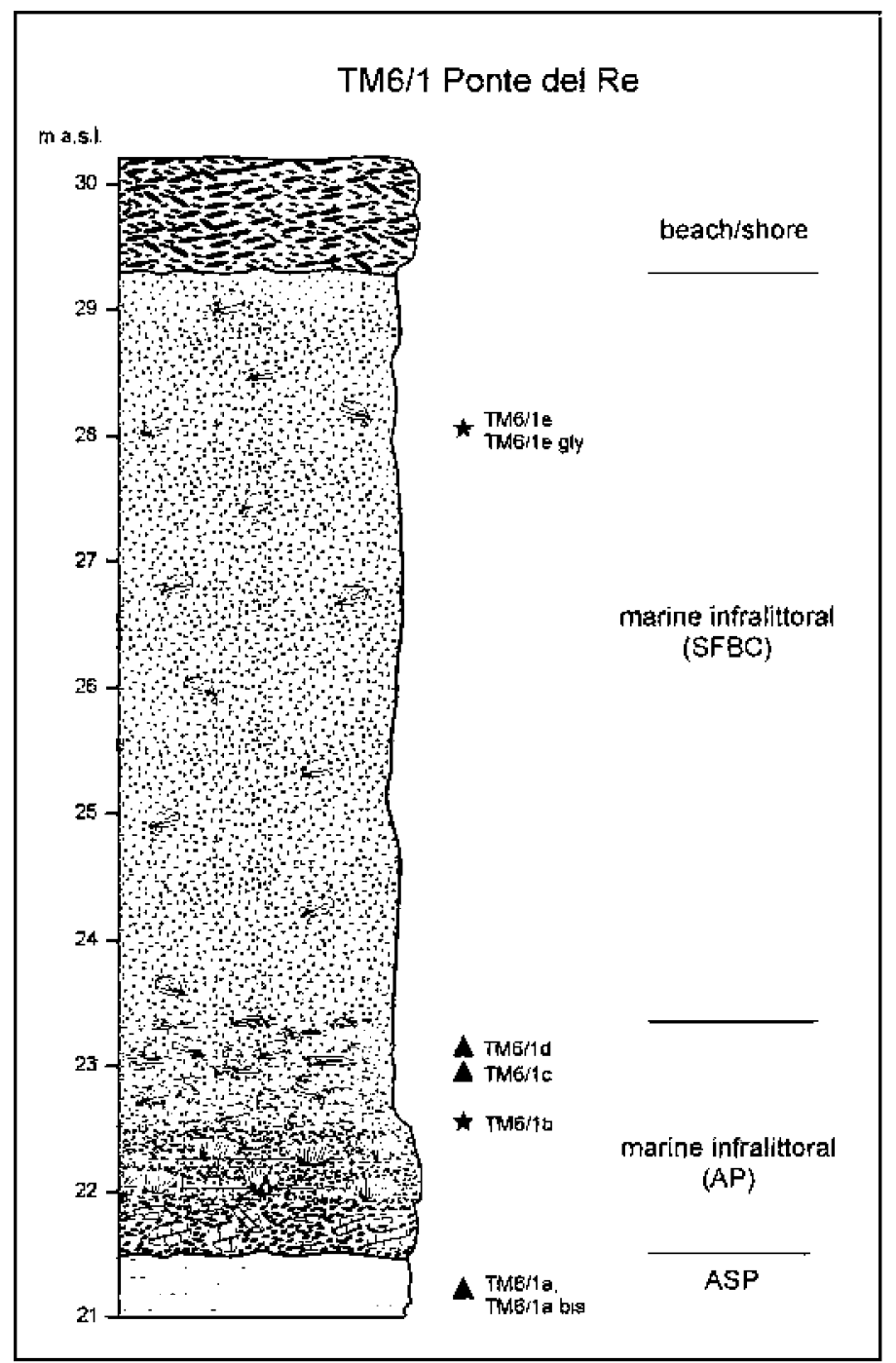

Fig. 10 - Stratigraphic column of the TM6/1 site, at the Ponte del Re locality. For symbols and acronyms, see the legend and caption in Fig. 4.

and Acanthocardia paucicostata. Finally, a third stock of species characteristic of infralittoral well-sorted fine sands biocoenosis (SFBC sensu PÉRÈs, 1967) is observed: Acanthocardia tuberculata, Glycymeris sp., Aequipecten opercularis, Lucinella divaricata, Spisula subtruncata, and Ensis sp. The assemblage is completed by fragments of crustaceans, spicules of siliceous sponges, bryozoans, and otoliths. Upward, the macrofauna becomes less rich and consists of Pododesmus patelliformis, Anomia ephippium, Corbula gibba, Spisula subtruncata, Aequipecten opercularis, and Nuculana pella. The microfaunal content of both of the first units is represented by planktonic and benthic foraminifera and ostracods, although the planktonic foraminifera content decreases upward.

The third unit in the succession is composed of greybeige fine clayey sands with calcareous nodules due to the chemical precipitation of $\mathrm{CaCO}_{3}$. At the base of this unit, there is a thin, approximately $5-\mathrm{cm}$-thick layer rich in Apenninic centimetric to sub-centimetric pebbles in a sandy matrix. The pebble content gradually decreases upwards. The macrofauna is represented exclusively by 
Glycymeris sp.

Finally, the uppermost part of the Masseria Perrone sequence is a gravelly unit composed of Apenninic heterometric pebbles and cobbles. The basal part of this unit contains reworked shells of Glycymeris sp., Cerastoderma sp., and Ostrea sp.

The palaeoenvironment of the first two units of the Masseria Perrone succession is characterised by heterogeneous associations (PE, sensu PICARD, 1965) indicative of sedimentary instability, likely due to a high sedimentation rate, with a shallowing from a circalittoral (terrigenous mud biocoenosis; VTC sensu Pérès, 1967) to an infralittoral environment (well-sorted, fine sands biocoenosis; SFBC sensu PÉRÈs, 1967). The regressive trend continues in the third unit, and gradation into a shore-beach environment is observed in the fourth unit.

The only bed from these sections that yielded a valid age via the AAR method with ostracod shells indicated an age of $97.3 \pm 18.9 \mathrm{ka}$ (Tab. 2). In addition, two samples of Glycymeris sp. yielded isoleucine epimerisation values (D-aIle/L-Ile ratios) of $0.436 \pm 0.048$ and $0.427 \pm 0.026$ (Tab. 3 ).

\section{TM6/6 and TM6/7 Cave Sarim}

These stratigraphic sections are located between the Masseria Stivaletta and Lame di Pozzo and consist of two fronts of many quarries that belong to the Sarim firm.

The three measured sections, one in the largest southern quarry and two in the smaller northern quarry (Fig. 12), overall show, a large prograding sedimentary body, more than $20 \mathrm{~m}$ thick, with seaward sloping clinoforms overlain by subhorizontal to gently seaward sloping beds.

The clinoforms are composed of beds of gravel of an Apenninic source, where each bed appears to be characterised by a uniform grain size and a different content of siliciclastic sandy matrix.

The subhorizontal to gently sloping beds show a fining-upward trend: the gravel beds decrease in number, thickness and grain size toward the top and are replaced by increasingly by sandy beds that increase in thickness upward. The uppermost part of the outcrops consists of fine sand and clay, ranging from light brown to grey. The faunal content, which is limited to the uppermost finer part, is oligotypic and represented by ostracods.

The deposits of these outcrops are related to a coastal prograding wedge with beach and nearshore environments at the bottom that pass upward into continental environments with freshwater episodes.

The only bed from these sections that yielded a valid age with the AAR method with ostracod shells indicated an age of $102 \pm 16 \mathrm{ka}$ (Tab. 2).

\section{DISCUSSION}

\section{GENERAL FRAMEWORK OF THE MIS 7 AND MIS 5 TERRACE DEPOSITS}

The combination of the field geological survey, remote sensing images, digital terrain model analysis, and absolute dating allowed us to recognise three terrace deposits, above the Holocene (modern) coastal plain (MIS 1), sloping slightly seaward, and correlating (from higher to lower) to MIS 7.3, MIS 7.1 and MIS 5 (Fig. 2). We also reconstructed
TM6/2 Masseria Perrone

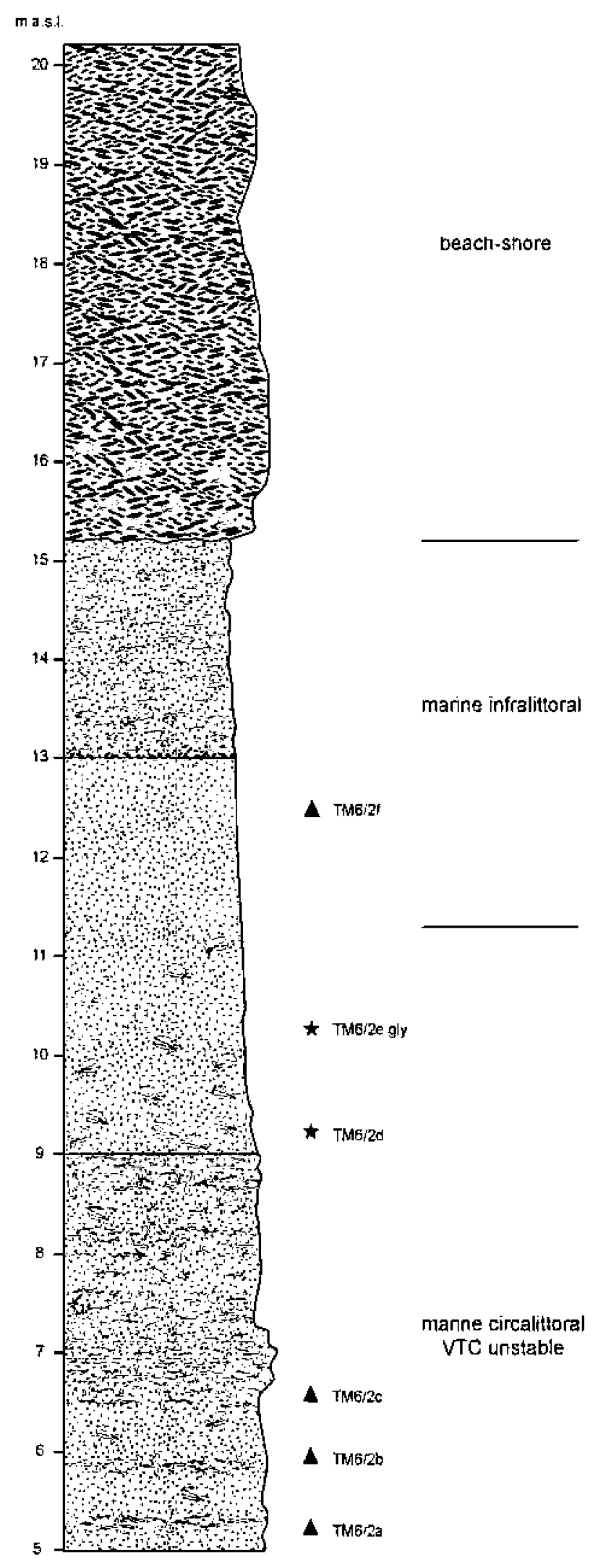

Fig. 11 - Stratigraphic column of the TM6/2 site, near Masseria Perrone. For symbols and acronyms, see the legend and caption in Fig. 4. 
the stratigraphic relationships between the three terrace deposits and their lateral and vertical relationships (Fig. 13).

Although the older cluster of absolute ages refers to MIS 7 and does not allow us to distinguish the substages, the field survey highlighted that the sites that provided the ages that are clustered around MIS 7 are distributed in two terraces, divided by an evident scarp. Thus, we assigned the substage 7.3 to the higher terrace and the substage 7.1 to the lower terrace.

Regarding the MIS 5 terrace, a more accurate chronological attribution to the substage scale must address the following uncertainties:

1) the scarps, which should mark the highstand peaks of the MIS 5 substages, are often masked by givoni, according to the evidence widely illustrated in DE SANTIS \& Caldara (submitted);

2) the ages obtained are distributed in some cases without a congruency with their stratigraphic position, and hence they allow us to recognise only a cluster of dates centred on MIS 5 (Fig. 3).

Due to these uncertainties, we formulate two hypotheses regarding the terrace deposit of MIS 5:

1) The entire terrace dates to MIS 5.5. Supporting this hypothesis is the fact that this highstand coincides with the greatest overlap of standard deviations and three ages based on the D-aIle/L-Ile values obtained from Glycymeris shells (Tab. 3).

2) The MIS 5 terrace includes parts of MIS 5.5, 5.3, and 5.1. Supporting this hypothesis are some ages that are shifted towards MIS 5.3 and 5.1 (Fig. 3), two ages based on the D-aIle/L-Ile values obtained from Glycymeris shells (Tab. 3) indicating MIS 5.3, and the evidence that the givoni can be divided into two main groups based on their orientation: the former, most inland, to which the Miraglio's givoni belong, oriented SW-NE, and the latter, nearest to the present coastline, which, starting from a SW$\mathrm{NE}$ orientation in the west part of the study area, passes into a WSW-ESE orientation towards the east part of the study area (Fig. 2). A possible limit between the MIS 5.5 and MIS 5.3 terrace is reported in Fig. 2. As stated earlier, it is important to underline that this limit is not an evident scarp: if a scarp exists, it is masked by givoni (DE SANTIS \& Caldara, submitted).

The dating of the deposit exposed at Ponte del Re has been the subject of particular attention and controversy.

Boenzi et alii (1985) and CALDARA (1987) correlated this deposit to the last interglacial (MIS 5.5) based on the rich fossil content that was interpreted as the Senegalese association.

In Glycymeris sp. shells from the bottom of this deposit just above the Cladocora caespitosa level, DaI PRA \& HEARTY (1992) found a D-alle/L-Ile value of $0.43 \pm 0.03$ (Tab. 1), which they used to assign the level to aminozone E, that is, MIS 5.5 (HeARTy et alii, 1986; HeARTy 1987).

CAPuto et alii (2010) used the same $\mathrm{D}$-alle/L-lle value found at Ponte del Re by DAI PRA \& Hearty (1992) to recalculate the age based on a review of the association between the D-aIle/L-Ile values and the MIS chronology

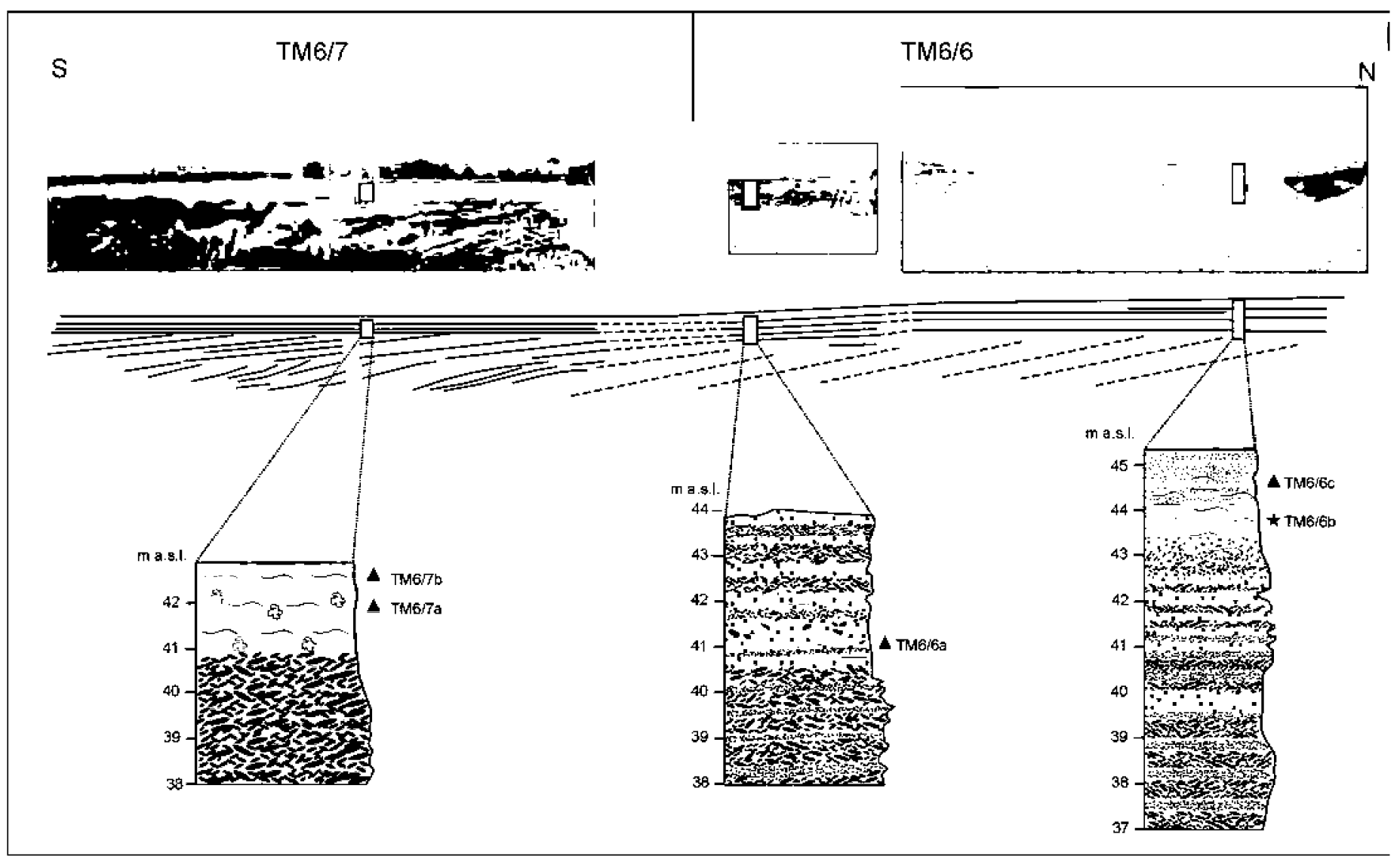

Fig. 12 - Stratigraphic sketch of Cave Sarim; TM6/6 (southern quarry) is at left, TM6/7 (northern quarry) is at right. The sedimentary structures and three stratigraphic columns are presented. For symbols and acronyms, see the legend and caption in Fig. 4. 
developed by Belluomini et alii (2002) and CALDARA et alii (2003), and they obtained an age of $99.4 \pm 9.7 \mathrm{ka}$ (MIS 5.3; Tab. 1).

According to our data, the previous assignment of the Ponte del Re deposit to MIS 5.5 by DaI PRA \& Hearty (1992) appears to be paradoxically exact. Paradoxically because it is based on an association between $\mathrm{D}$-alle/L-Ile ranges and MIS chronology superseded by more recent data (Belluomini et alii, 2002; Caldara et alii, 2003; Torres et alii, 2013) and on D-aIle/L-Ile value that is not confirmed by our results. In fact, our value obtained at Ponte del $\mathrm{Re}$ $(0.48 \pm 0.056)$ does not confirm that of DaI PRA \& HEARTY (1992).

In this framework, the lagoonal and fluvial deposits of Fontana del Fico deserve special mention. This site is located in an embayment on the inner edge of the terrace (Fig. 2). The lagoonal deposit (Fig. 8) is dated to MIS 5.5 (Tab. 1), and the overlying freshwater deposits yield ages that are compatible with MIS 5.3.

However, in the freshwater sediments, the presence of Melanoides tuberculata, a thermophilous gastropod widespread in tropical and subtropical Quaternary deposits (Williamson, 1981) and in Europe is reported only in Spain within 1.4 Ma deposits (ANADóN et alii, 2015), suggests water temperatures between $18^{\circ} \mathrm{C}$ and $32^{\circ} \mathrm{C}$ (Mitchell \& BRANDT, 2005). Therefore, it is reasonable to argue that the freshwater sediments of Fontana del Fico also date to the warmest phase of MIS 5.

Based on these data, it is possible to conclude that during the MIS 5.5 highstand and the contemporaneous creation of the inner edge of the terrace, a bay that was likely limited by a spit or a barrier formed at Fontana del Fico at or near the mouth of the Lenne River. This bay then became a lagoon connected to the sea. Later, because of the development of the sedimentary coastal wedge and the progradation of the shoreline, the lagoon was replaced by a fluvial freshwater environment.

UNCERTAINTIES IN THE ATTRIBUTION OF MIS 3 TERRACES
Two main schools of thought are in opposition regarding the estimated uplift rates along the Gulf of Taranto. The first follows CAPuTO et alii (2010) and is based on identifying one or more emerged terraces that are attributed to MIS 3. These terraces yield uplift rates equal to or greater than $1 \mathrm{~mm} / \mathrm{a}$ after MIS 5.5. Indeed, only these rates allow for the presence of an emerged MIS 3 terrace because during MIS 3 , the reconstructed typical sea level elevations were 60 and $80 \mathrm{~m}$ below present-day sea level during the earlier and later parts of the stage, respectively (WAELBROECK et alii, 2002; SIDDALL et alii, 2008).

The emerged MIS 3 terrace in question is the Policoro terrace, assigned precisely to MIS 3.3 by CAPUTO \& BIANCA (2009) and CAPUTO et alii (2010). According to these authors this chronological attribution is confirmed by absolute ages that come from two sites that both belonging to the Policoro terrace; these sites are Piano San Nicola and La Petrulla.

Specifically, at the Piano San Nicola site, DAI PRA \& Hearty (1992) found a D-alle/L-Ile value of $0.29 \pm 0.02$ in Glycymeris sp. shells of the terraced deposit, thus attributing it to aminozone $\mathrm{C}$, which is MIS 5.3-5.1. CAPUTO et alii (2010) applied the empirical relationship of Belluomini et alii (2002) between $\mathrm{D} / \mathrm{L}$ ratios and $\mathrm{Th} / \mathrm{U}$ numerical ages to the $\mathrm{D} / \mathrm{L}$ value of $\mathrm{D}_{A I} \mathrm{P}_{\mathrm{RA}}$ \& HEARTY (1992) and obtained an age of $54.2 \pm 6.5 \mathrm{ka}$ that corresponds quite well with MIS 3.3. In addition, according to CAPUTO \& BiANCA (2009) and CAPUTO et alii (2010), this attribution to MIS 3 is confirmed by the dating performed at La Petrulla site by ZANDER et alii (2006) and BRUCKNER (1980a).

The second school of thought, however, denies the presence of the emerged MIS 3 terraces (TROPEANo et alii, 2013) and argues that the uplift rates were too low to allow for their subaerial preservation. In fact, TROPEANo et alii (2013) studied boreholes drilled in the coastal plain of the Gulf of Taranto between the Bradano and Cavone Rivers and identified a unit whose upper part is at 20 and $30 \mathrm{~m}$ below the present sea level and for which an attribution to MIS 3 can be inferred. According to the authors, this finding implies that identifying deposits of MIS 3 above modern sea level is unlikely, and they also highlighted certain

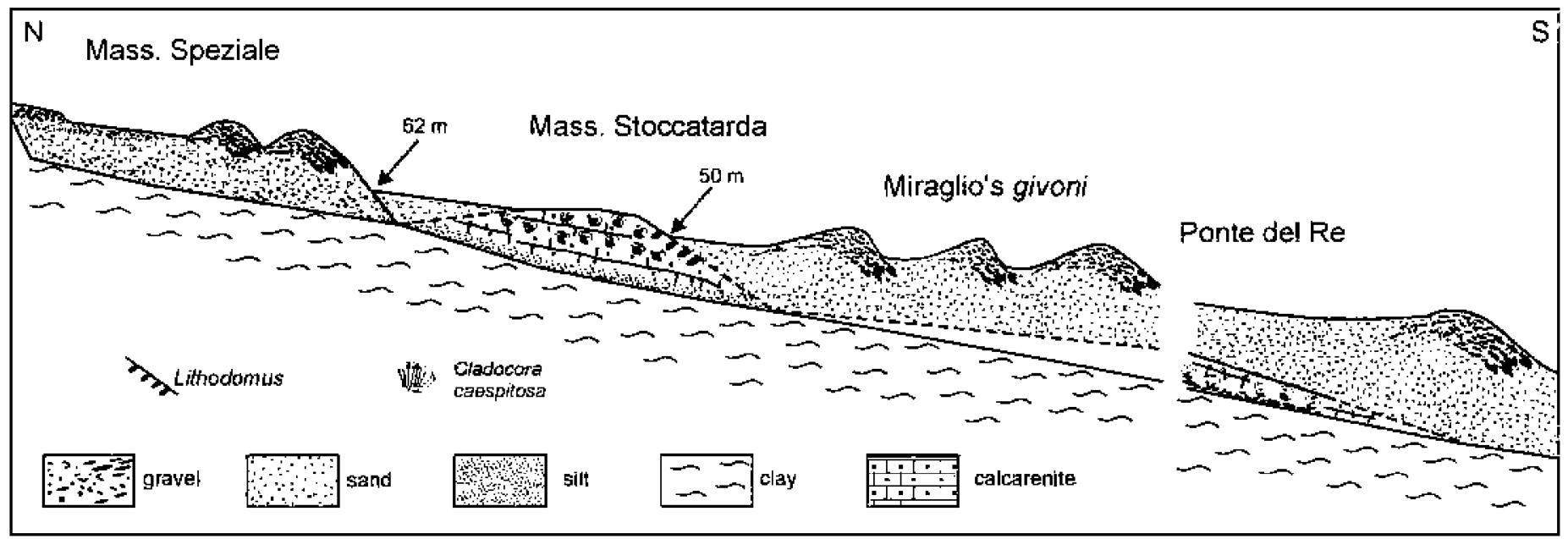

Fig. 13 - Schematic sketch of reciprocal stratigraphic relations between the MIS 7.3 (dark grey background), 7.1 (light grey background) and MIS 5 (white background) terrace deposits. The present elevations above sea level of the inner edges of the terraces are reported. 
stratigraphic constraints that lead them to regard MIS 3 as the only possible stage to which the unit can be assigned.

Our data are consistent with this second school of thought.

In addition, we believe that certain considerations are necessary regarding the absolute dates that would support the hypothesis of an emerged MIS 3 terrace, at least in our study area.

We ignore the Piano San Nicola locality because it is located in a geodynamic setting that is very different from ours. Regarding the absolute ages of La Petrulla, which is located approximately $8 \mathrm{~km} \mathrm{SE}$ of the Bradano River mouth and close to our study area, 8 luminescence ages were obtained from quartz, feldspar and fine-grained samples only in the marine part of the deposit (ZANDER et alii, 2006) and 2 absolute ages were published by BRÜCKNER (1980a) using the U/Th method. The 10 dates that are available for the marine part of the deposit are contradictory. BRÜCKNER (1980a) dated the section to $75 \pm 7 \mathrm{ka}$ and $63 \pm 3 \mathrm{ka}$, which places the deposit between MIS 5.1 and MIS 3. ZANDER et alii (2006) observed strong discrepancies between the absolute ages obtained from quartz, fine-grain and feldspar samples, with the former ranging from a maximum of $130 \pm 18 \mathrm{ka}$ at the bottom to a minimum of $99.4 \pm 18.2 \mathrm{ka}$ at the top and the latter ranging between a maximum of $73.8 \pm 6.5 \mathrm{ka}$ and a minimum of $49.4 \pm 3.8 \mathrm{ka}$. ZANDER et alii (2006) concluded that the terrace likely formed during MIS 5.1.

To conclude, the use of the dates previously obtained at La Petrulla by BRÜCKNER (1980a) and ZANDER et alii (2006) as a contribution to the sure assignment of the Policoro terrace to MIS 3.3, as proposed by CAPUTO \& Bianca (2009) and CAPUTO et alii (2010), appears to be premature. In our opinion, the dates of the La Petrulla locations would need further insight because they are still too contradictory.

\section{VERTICAL MOVEMENTS}

When assessing vertical movements based on marine terraces, the inner edge, which is considered a palaeoshoreline, is generally a crucial element (LAJoIE, 1986).

In this work, we used palaeoshorelines along the inner edge of the terrace and dated layers deposited close to palaeo-sea level (sea level markers). Both elements and the reconstruction of vertical movements based on marine terraces in general are based on certain necessary conditions and assumptions, including the following:

1) the inner edge coincides with the palaeoshoreline only if it is etched into the substrate (CAROBENE, 1980);

2) when using the dated layers that were deposited close to palaeo-sea level, the uncertainty of the depth range of these deposits must be minimised (LAMBEck et alii, 2004); in addition, it is necessary to address the age, which always involves a standard deviation within various ranges; and

3 ) the sea levels that correspond to the recognised palaeoshorelines or dated layers could differ by tens of metres depending on the authors. In addition, the age of a given highstand could differ by tens of thousands of years depending on authors.

Thus, we used the following indicators to define the palaeoshorelines and to calculate the vertical movement. First, we considered inner edges that were not masked by younger deposits and etched into the substrate on which the terrace deposit lies. Second, we considered dated sea level indicators. Finally, only if the first two are not available, we considered the inner edge as it is.

Regarding the palaeoshoreline of MIS 5.3, its position, to date, can be only hypothesised (Fig. 2) ca. $35 \mathrm{~m}$ at the west sector, $30 \mathrm{~m}$ at the central sector, and $25 \mathrm{~m}$ at the east sector. In this work, an MIS 5.3 highstand at $+2 \div 5$ $\mathrm{m}$ is assumed (CoYNe et alii, 2007). To calculate the uplift rate, we consider the age of this inner edge ca. $95 \div 110 \mathrm{ka}$ $\mathrm{BP}$ (Coyne et alii, 2007). Based on these data, we estimate

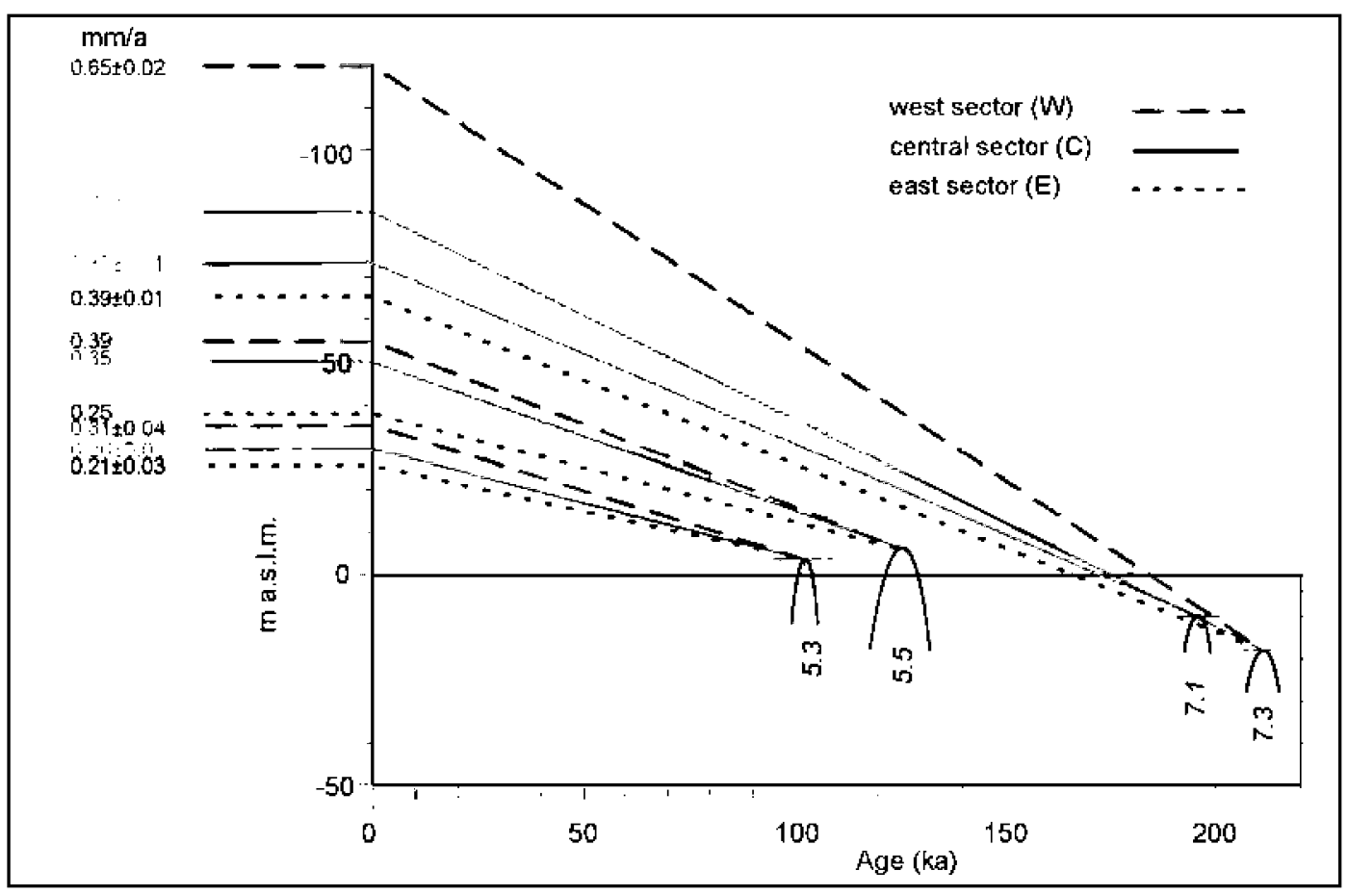

Fig. 14 - Vertical uplift for each inner edge recognised in our study area. Each segment join the present inner edge elevation (vertical axis) with the highstand of its formation; for each inner edge the elevations are reported in the three sectors and related uplift rates. West sector $(\mathrm{W})$ : left side of Bradano River; Central sector (C): close to Lato River; East sector (E): east of Lenne River. The horizontal and vertical bars on highstand peaks indicate age and sea level depth uncertainties. The highstand peaks are reported according to the authors specified in the text. 
that the palaeoshoreline of the MIS 5.3 terrace (if exists) experienced an uplift of $30 \div 33,25 \div 28$, and $20 \div 23 \mathrm{~m}$ at the west, central and east sectors, with uplift rates of ca. $0.31 \pm 0.04$, ca. $0.26 \pm 0.03$, and ca. $0.21 \pm 0.03$ respectively (Fig. 14).

Regarding the palaeoshoreline of MIS 5.5, it cannot be identified precisely in the west sector; thus, we must consider the inner edge of the terrace as it is, located ca. $55 \mathrm{~m}$.

At location TM5/17, in the central sector of our study area, we identified the palaeoshoreline precisely and mapped it based on the concentration of holes bored by Lithodomus in the carbonate bedrock of MIS 7.1, ca. 50 $m$ above the current sea level (figs. 6, 13) and filled by transgressive siliciclastic sandstone. Although no absolute dates are available for the transgressive sandstone, the lack of marine deposits at higher elevations constitutes a chronological constraint for this palaeoshoreline that can be reasonably attributed to MIS 5.5 highstand; thus, we assign an age of $125 \mathrm{ka}$ to this palaeoshoreline (WAELBROECK et alii, 2002).

At Fontana del Fico, in the east sector of our study area, we did not locate a palaeoshoreline precisely, although the sea level can be reconstructed to a good approximation based on the lagoonal layer that was dated to $127.1 \pm 29.0$ ka (Tab. 2, Fig. 8). To calculate the uplift rate, we round this date to $127 \mathrm{ka}$ (point 2). Furthermore, according to Gravina et alii (1989) and LAMBEcK et alii (2004), a maximum sedimentation depth of $2 \mathrm{~m}$ can be attributed to the lagoon bottom. Therefore, the lagoonal layer of Fontana del Fico allows us to reconstruct a palaeo sea level dated to $127 \mathrm{ka}$ and located $2 \mathrm{~m}$ above the current position of the lagoon layer, i.e., $36 \mathrm{~m}$ a.s.l.. Published data regarding the sea level position during MIS 5.5 (point 3) are similar. WAELBROECK et alii (2002) reported that the sea level was at $+6 \mathrm{~m}$; however, LAMBECK et alii (2004) placed it at $+6 \pm 3 \mathrm{~m}$. HeARTY et alii (2007) identified a maximum sea level at between +6 and $+9 \mathrm{~m}$, and CoYne et alii (2007) identify a maximum sea level at +6 .

In this work, an MIS 5.5 highstand at $+6 \mathrm{~m}$ was considered because this is the most common value among those reported in the literature.

Based on these data, we estimate that the palaeoshoreline of the MIS 5.5 terrace in the west sector of the study area experienced an uplift of $49 \mathrm{~m}$ within $125 \mathrm{ka}$, at an uplift rate of $0.39 \mathrm{~mm} / \mathrm{a}$ (Fig. 14).

The same palaeoshoreline experienced an uplift of $44 \mathrm{~m}$ within $125 \mathrm{ka}$, at an uplift rate of $0.35 \mathrm{~mm} / \mathrm{a}$ in the central sector, while experienced an uplift of $32 \mathrm{~m}$ at an uplift rate of $0.26 \mathrm{~mm} / \mathrm{a}$ in the east sector (Fig. 14).

Regarding the MIS 7.1 terrace, we can only consider the inner edge as it is, only in the central sector. Currently it is always located ca. $62 \mathrm{~m}$ a.s.l. To calculate the uplift rate, we consider the age of this inner edge at ca. $189.7 \div 201.5$ ka BP (DutTon et alii, 2009). In addition, we assume a 7.1 highstand ca. $-10 \mathrm{~m}$ (WAELBRoEk et alii, 2002). Thus, the MIS 7.1 palaeoshoreline would have experienced a 72 -metre uplift, with an uplift rate of ca. $0.37 \pm 0.01 \mathrm{~mm} / \mathrm{a}$ (Fig. 14).

Also regarding the MIS 7.3 terrace, we can only consider the inner edge as it is. Currently this edge is located between ca. $120 \mathrm{~m}$ a.s.l. in the west sector, ca. 85 $\mathrm{m}$ a.s.l. in the central sector, and ca. 65 a.s.l. in the east sector. To calculate the uplift rate, we consider the age of this inner edge ca. $206 \div 217.2 \mathrm{ka}$ BP (DutTon et alii, 2009). In addition, we consider a 7.3 highstand ca. $-18 \mathrm{~m}$ (DutToN et alii, 2009). Thus, the MIS 7.3 palaeoshoreline would have experienced an uplift ranging from $138 \mathrm{~m}$ in the west, to $103 \mathrm{~m}$ in the centre, to $83 \mathrm{~m}$ in the east. The resulting uplift rate ranges from ca. $0.65 \pm 0.02 \mathrm{~mm} / \mathrm{a}$ in the west, to ca. $0.485 \pm 0.015 \mathrm{~mm} / \mathrm{a}$ in the centre, to ca. $0.39 \pm 0.01 \mathrm{~mm} / \mathrm{a}$ in the east (Fig. 14).

Although the data are not numerous enough to be able to identify a precise trend, the pattern of uplift rates we obtained appears to be much more uniform than those obtained using the data of BRÜCKNER (1980a, b; 1982) and, above all, those reported in CAPUTO et alii (2010) (Fig. 15). In general, while these last data show a tendency to increase of the uplift rates towards more recent times, our data show a tendency to decrease. The uplift of the terraces we recognised occurs at a time when the shortening in the Apennines and the frontal blind thrust (that is, basal detachment) had just been de-activated (Cingue et alii, 1993; Patacca \& Scandone, 2001, 2004). This de-activation occurs in the middle Pleistocene at approximately 0.65 Ma (Patacca \& Scandone, 2001, 2004), so, much before the formation and subsequent uplift of the terraces of our study area. This deactivation falls within the change in the deformation style in the southern Apennine which has been widely recognised during the middle Pleistocene: it transitioned from dominantly thrust tectonics to a regime dominated by a widespread regional uplift (BORDONI \& Valensise, 1999; SchiaTTARELla et alii, 2017).

Since the uplift of the terraces reconstructed in this work occurred in a period following this change of deformation style, it is related to the more generalised uplift that characterised the chain and the foredeep starting from middle Pleistocene, whose cause is at present still a matter of debate, e.g.: slab rupture rebound (CINQUE et alii, 1993; WestaWAY, 1993), mantle upwelling (D'Agostino et alii, 2001; LAVEcCHIA et alii, 2003), slab window (FACCENNA et alii $(2007,2014)$.

Our data do not allow to add anything to the debate on the cause of this generalised uplift of the Apennines and the foredeep started in the middle Pleistocene, but allow us to hypotesise a slowdown of this uplift and, perhaps, consequently, of the mechanism invoked to justify it.

\section{CONCLUSIONS}

We identified three marine terrace deposits along the Apulian sector of the Gulf of Taranto that correlate to MIS 7.3, 7.1 and MIS 5. We developed two hypotheses regarding the chronology of the MIS 5 terrace. For the first time, this work refutes an arcuate morphology of the inner edges of terraces, at least in the Apulian sector of the Gulf of Taranto, so far reconstructed to be more or less subparallel to the current shoreline. The palaeoshoreline of the MIS 5.5 terrace at the Masseria Stoccatarda high provides strong support, and this palaeoshoreline configuration was most likely due to the particular lithology of the substrate, which is carbonate cemented and therefore more resistant.

We deny the presence of a terrace of MIS 3, also through a critical review of the dating that has been used to support its presence. The absence of MIS 3 terraces has important implications for uplift rates. 


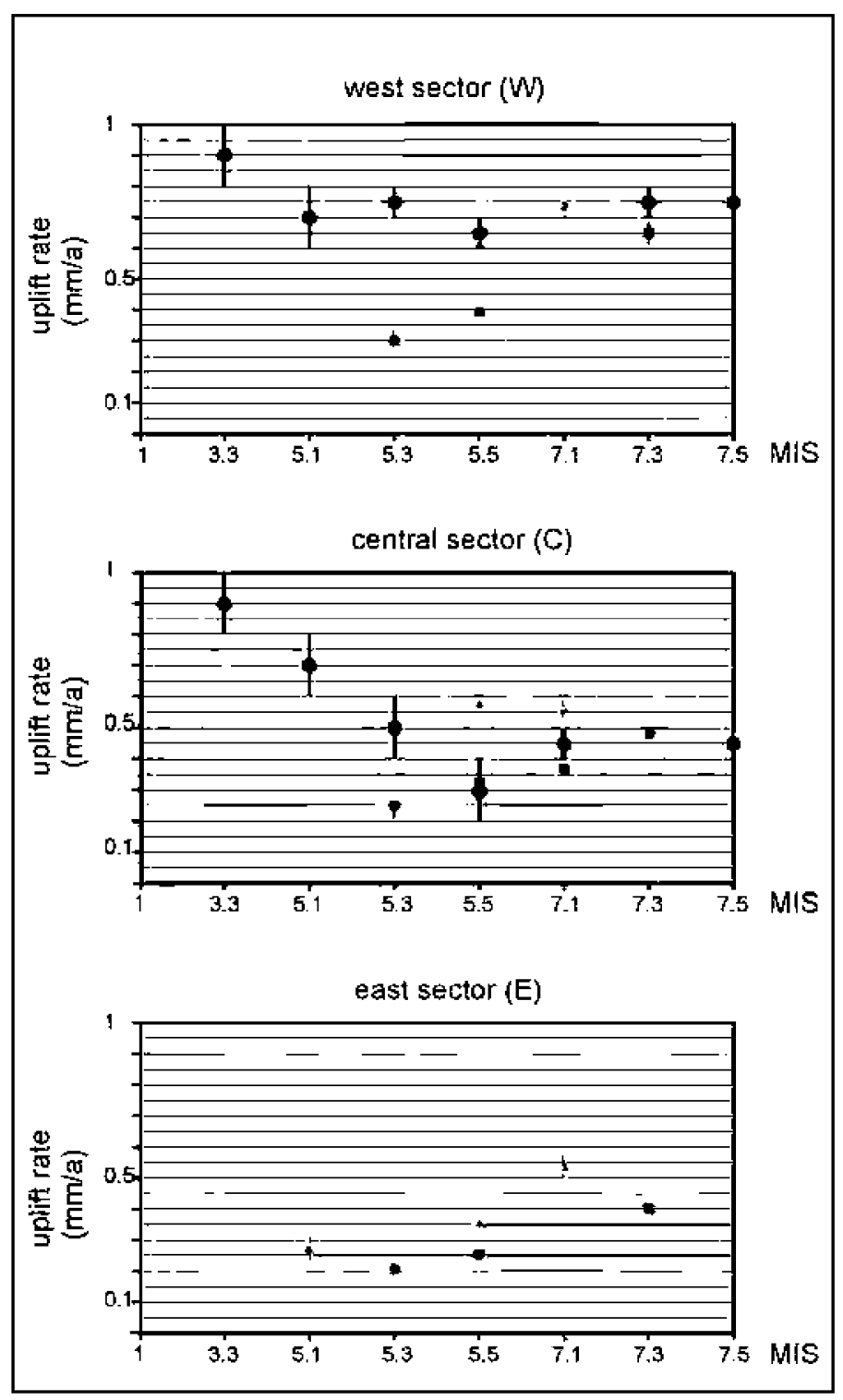

Fig. 15 - Comparison between uplift rates calculated for the inner edges recognised in our study area; squares = this study, circles = CAPUTo et alii (2010), triangles = BRÜCKNER (1980a, b; 1982). For the uplift rates of CAPUTO et alii (2010) and BRÜCKNER (1980a, b; 1982) refer to table 1; for the uplift rates of this study cfr. "vertical movement" section.

We calculated the uplift rates of MIS 7.3, 7.1, 5.5 and 5.3 palaeoshorelines, which show a clear decreasing trend; this allows us to hypothesise a slowing of this uplift and, perhaps, consequently, of the mechanism invoked to justify it (e.g., slab rupture rebound, mantle upwelling, slab window).

\section{ACKNOWLEDGEMENTS}

We thank Domenico Capolongo for providing a fruitful discussion and sharing accurate stratigraphic and morphological information regarding the marine terraces and marine terrace deposits of the Bradanic Trough.

We thank the Biomolecular Stratigraphy Laboratory of the Polytechnical University of Madrid for sample datings with the AAR method.

\section{REFERENCES}

Amato A., Belluomini G., Cinque A., Manolto M. \& Ravera F. (1997) Terrazzi marini e sollevamenti tettonici quatemari lungo il margine ionico dell'Appennino lucano. Il Quaternario 10(2), 329-336.

Anadón P., Oms O., Riera V. \& Julià R. (2015) - The geochemistry of biogenic carbonates as a paleoenvironmental tool for the Lower Pleistocene Barranco León sequence (BL-5D, Baza Basin, Spain). Quaternary International, 389, 70-83

Azzaroli A., Perno V. \& Radina B. (1968) - Note illustrative della Carta Geologica d'Italia, $F^{\circ} 188$ Gravina di Puglia. Servizio Geologico d'Italia, Roma.

Bardají T., Goy J.L., Zazo C., Hillatre-Marcel C., Dabrio C.J. Cabero A. Ghaleb B., Silva P.G. \& Lario J. (2009) - Sea level and climate changes during OIS $5 e$ in the Western Mediterranean. Geomorphology, 104, 22-37.

Bar-Matthews M., Ayalon A., Gilmou M., Matthews A. \& Hawkesworth C.J. (2003) - Sea-land oxygen isotopic relationships from planktonic foraminifera and speleothems in the Eastern Mediterranean region and their implication for paleorainfall during interglacial intervals. Geochimica et Cosmochimica Acta, 67(17), 3181-3199.

Belluomini G., Caldara M., Casini C., Cerasoli M., Manfra L., Mastronuzzi G., Palmentola G., Sansò P., Tuccimei P. \& Vesica P.L. (2002) - The age of Late Pleistocene shorelines and tectonic activity of Taranto area, Southern Italy. Quaternary Science Reviews, 21, $525-547$.

Bentivenga M., Coltorti,M., Prosser G. \& Tavarnelli E. (2004a) Deformazioni distensive recenti nell'entroterra del Golfo di Taranto: Implicazioni per la realizzazione di un deposito geologico per scorie nucleari nei pressi di Scanzano Ionico (Basilicata). Bollettino Società Geologica Italiana, 123, 391-404.

Bentivenga M., Coltorti M., Prosser G. \& Tavarnelli E. (2004b) - A new interpretation of terraces in the Taranto Gulf-the role of extensional faulting. Geomorphology, 60, 383-402.

Bianca M. \& Caputo R. (2003) - Analisi morfotettonica ed evoluzione quatemaria della Vald'Agri, Appennino meridionale. Il Quaternario, 16(2), 159-170

Bintanja R., van de WAL R.S.W. \& Oerlemans J. (2005) - Modelled atmospheric temperatures and global sea levels over the past million years. Nature, letters, 437(1), 125-128.

Boenzi F., Caldara M. \& Pennetta L. (1985) - La trasgressione tirreniana nei dintorni di Castellaneta (TA). Geologia Applicata e idrogeologia, 20(1), 163-175

Boenzi F., Palmentola G. \& Valduga A. (1977) - Caratteri geomorfologici dell'area del Foglio Matera. Bollettino Società Geologica Italiana, 95, 527-566.

Bordoni P. \& Valensise G. (1999) - Deformation of the $125 \mathrm{ka}$ marine terrace in Italy: tectonic implications. In: STEWART I.S. \& VITA FINZI C. (Eds.), Coastal Tectonics. Geological Society, London, Special Publications, 146, 71-110.

Bosi C., Carobene L. \& Sposato A. (1996) - Il ruolo dell'eustatismo nell'evoluzione geologica dell'area mediterranea. Memorie Società Geologica Italiana, 51, 363-382.

BRÜCKNER H. (1980a) - Marine Terrassen in Süditalien. Eine quartärmorphologische Studie über das Küstentiefland von Metapont. Düsseldorfer Geographische Schriften, 14, 1-235.

BRÜCKNER H. (1980b) - Flussterrassen und Flusstäler im Küstentiefland von Metapont (Süditalien) und ihre Beziehung zu Meeresterrassen. Düsseldorfer Geographische Schriften, 15, 5-32.

BrǘcKNer H. (1982) - Ausmass von Erosion und Akkumulation im Verlauf des Quartärs in der Basilicata (Süditalien). Zeitschrift fur Geomorphologie N.F., 43 suppl., 121-137.

BRÜCKNER H. (1983) - Ein modell zur genese mariner akkumulationsterrassen. Essender Geogr. Arb., 6, 161-186.

Caldara M. (1987) - La sezione tirreniana di Ponte del Re (Castellaneta Marina, Taranto): analisi paleoecologica. Atti Società Toscana di Scienze Naturali Memorie, serie A, 93(1986), 129-163.

Caldara M., Iannone A., Lopez R., Simone O., De Santis V., Torres T. \& Ortiz J.E. (2013) - New data on the Pleistocene of Trani (Adriatic coast, southern Italv). Italian Journal of Geosciences, 132(2), 239 253.

Caldara M., Mastronuzzi G., Palmentola G., Sansò P., Tuccimei P. \& VESICA, P.L. (2003) - Reply to the comment by Hearty, P.J., Dai Pra, G. Quaternary Science Reviews, 22, 2369-2371. 
Caputo R. \& Bianca M. (2009) - Comment on "Late Cenozoic uplift of southern Italy deduced from fluvial and marine sediments: coupling between surface processes and lower-crustal flow" by Rob Westaway and David Bridgland. Quaternary International, 204, 98-102

CAPUto R., BiAnca M. \& D'OnofRto R. (2010) - Ionian marine terraces of southern Italy: Insights into the Quatemary tectonic evolution of the area. Tectonics, 29(4), TC4005, doi:10.1029/2009TC002625, 2010

CARobene M. (1980) - Terrazzi Marini: eustatismo e neotettonica. Geografia Fisica e Dinamica Quaternaria, 3(2), 35-41

Chappell J., Omura A., Esat T, McCulloch M., Pandolfi J., Ota Y. \& PIllans B. (1996) - Reconciliation of late Quaternary sea levels derived from coral terraces at Huon Peninsula with deep sea oxygen isotope records. Earth and Planetary Science Letters, 141, 227 236.

Ciaranfi N., Pieri P. \& Ricchetti G. (1992) - Note alla carta geologica delle Murge e del Salento Puglia centromeridionale. Memorie Società Geologica Italiana, 41(1988), 449-460.

Cilumbriello A., Tropeano M. \& Sabato L. (2008) - The Ouaternary terraced marine-deposits of the Metaponto area (Southern Italy) in a sequence-stratigraphic perspective. Geoacta, special publication 1(2008), 29-54.

Cinque A., De Pippo T. \& Romano P. (1995) - Coastal slope terracing and relative sea-level changes: deductions based on computer simulations. Earth surfaces processes and landforms, 20, 87-103.

Cinque, A., Patacca E., Scandone P. \& Tozzi M. (1993) - Quaternary kinematic evolution of the southern Apennines. Relationship between surface geological features and deep lithospheric structures. Annali di. Geofisica, 36(2), 249-260.

Coyne M.K., Jones B. \& Derek F. (2007) - Highstands during Marine Isotope Stage 5: evidence from the Ironshore Formation of Grand Cayman, British West Indies. Quaternary Science Reviews, 26. 536-559.

CuCcI L. \& CINTI F.R. (1998) - Regional uplift and local tectonic deformation recorded by the Quaternary marine terraces on the Ionian coast of northern Calabria (southern Italy). Tectonophysics, 292(1-2), 67-83

D'agostino N., Jackson J.A., Dramis F. \& Funtciello R. (2001) Interactions between mantle upwelling, drainage evolution and active normal faulting: an example from the central Apennines (Italy). Geophysical Journal International, 147, 475-479.

DaI PRa G. \& Hearty P.J. (1992) - I livelli marini pleistocenici del Golfo di Taranto, sintesi geocronostratigrafica e tettonica. Memorie Società Geologica Italiana, 41(1988), 637-644.

De Santis V., Caldara M. \& Pennetta L. (2014a) - The marine and alluvial terraces of Tavoliere di Puglia plain (southern Italy). Journal of Maps, 10(1), 114-125.

De Santis V., Caldara M., Pennetta L., Torres T. \& Ortiz J.E. (2013) Unconformity Bounded Stratigraphic Units in an Italian alluvial plain area: recognising and dating. Journal of Sedimentary Research, 83, 96-114.

De Santis V., Caldara M., Torres T. \& Ortiz J.E. (2010) - Stratigraphic units of the Apulian Tavoliere Plain: chronology, correlation with marine isotope stages and implication regarding vertical movements. Sedimentary Geology, 228, 255-270.

De Santis V., Caldara M., Torres T. \& Ortiz J.E. (2014b) - Two middle pleistocenic warm stages in the Terraced Deposits of the Apulia Region (southern Italy). Quaternary international, 332, 2-18.

De SAntis V. \& Caldara M. (submitted) - The role of beach ridges, spits or barriers (so-called givoni) in understanding the process of the formation and evolution of marine terraces on loose or semiconsolidated substrates. Geomorphology.

Doglioni C., Mongeldi F. \& Pieri P. (1994) - The Puglia uplift (SE Italy): an anomaly in the foreland of the Apenninic subduction due to buckling of a thick continental lithosphere. Tectonics, 13(5), 1309-1321.

Doglioni C., Tropeano M., Mongelli F. \& Pieri P. (1996) - Middle-late Pleistocene uplift of Puglia: an anomaly in the Apenninic foreland. Memorie Società Geologica Italiana, 51, 101-117.

Dutton A., Bard E., Antonioli F., Esat T.M., Lambeck K., \& McCulloch M.T. (2009) - Phasing and amplitude of sea-level and climate change during the penultimate interglacial. Nature Geoscience 2, 355-359. Faccenna C., Becker T.W., Miller M.S., Serpelloni E., Willett S.D. (2014) - Isostasv, dynamic topography, and the elevation of the Apennines of Italy. Earth and Planetary Science Letters, 407, 163-174.
Faccenna C., Funiciello F., Civetta L., D’Antonio M., Moroni M. \& Piromallo C. (2007) -Slab disruption, mantle circulation and the opening of the Thyrrenian basin. Geological Society of America Special paper, 418, 153-169.

Ferranti L., Antontoli F., Mauz B., Amorosi A., Dai Pra G., Mastronuzz G., Monaco C., Orru P., Pappalardo M., Radtke U., Renda P., Romano P., Sansò P. \& VerrubBi V. (2006) - Markers of the last interglacial sea-level high stand along the coast of Italy: Tectonic implications. Quaternary International, 145-146, 30-54

Giota D., Bavusi M., Di Leo P., Giammatteo T. \& Schiattarella M. (2016) - A geoarchaeological study of the Metaponto coastal belt, Southern Italy, based on geomorphological mapping and gis-supported classification of landforms. Geogr. Fis. Dinam. Quat., 39, 137-148.

Gravina M.F., Ardizzone G.D., Scaletta F. \& Chimenz C. (1989) Descriptive analysis and classification of benthic communities in some Mediterranean coastal lagoons (central Italy). Marine Ecology, 10, 141-216.

HeARTy P.J. (1987) - New data on the Pleistocene of Mallorca. Quaternary Science Reviews, 6, 245-257.

HeARTy P.J. \& DAI PRA G. (1992) - The age and stratigraphy of Midale Pleistocene and younger deposits along the Gulf of Taranto (southeast Italy). Journal of Coastal Research, 8, 882-905.

Hearty P.J., Miller G., Stearns C. \& Szabo B.J. (1986) Aminostratigraphy of Quaternary shorelines in the Mediterranean basin. Geological Society of America Bulletin, 97, 850-858.

Hearty P.J., Hollin J.T., Neumann A.C., O’Leary M.J. \& McCulloch M. (2007) - Global sea-level fuctuations during the last Interglaciation (MIS 5e). Quaternary Science Reviews, 26, 2090-2112.

Hearty P.J., O'Leary M.J., Kaufman D.S., Page M. \& Bright J. (2004) Amino acid geochronology of individual foraminifer (Pulleniatina obliquiloculata) tests, north Queensland margin, Australia: a new approach to correlating and dating Quaternary tropical marine sediment cores. Paleoceanography, 19, PA4022, doi: 10.1029/2004PA001059.

KosNIK M.A. \& KaUFMAN D.S. (2008) - Identifying outliers and assessing the accuracy of amino acid racemization measurements for geochronology: II. Data screening. Quaternary Geochronology, 3, 328-341.

Lambeck K., Antonioli F., Purcell A. \& Silenzi S. (2004) - Sea-level change along the Italian coast for the past 10,000 yr. Quaternary Science Reviews, 23, 1567-1598.

LajoIE K.R. (1986) - Coastal tectonics. In: Active tectonics. National Academy Press, Washington D.C., 95-124.

Lavecchia G., Boncio P., Creati N. \& Brozzetti F. (2003) - Some aspects of the Italian geology not fitting with a subduction scenario. Journal of the Virtual Explorer, 10, 1-14.

Laviano A. \& Pennetta L. (1980) - Il deposito continentale pleistocenico di Fontana del Fico. Osservazioni stratigrafiche e paleontologiche. Rivista italiana di Paleontologia, 86(2), 429-452.

Mastronuzzi G. \& Sansò P. (2002) - Pleistocene sea level changes, sapping process and development of valley networks in the Apulia region (southern Italy). Geomorphology, 46, 19-34.

Mauz B., Fanelli F., Elmejdoub N. \& Barbieri R. (2012) - Coastal response to climate change: Mediterranean shorelines during the Last Interglacial (MIS 5). Quaternary Science Reviews, 54, 89-98.

Mitchell A.J. \& BRANDT T.M. (2005) - Temperature tolerance of redrim Melania Melanoides tuberculatus, an exotic aquatic snail established in the United States. Transactions of the American Fisheries Society, 134, 126-131.

Murray-Wallace C.V. (1995) - Aminostratigraphy of Quaternany coastal sequences in Southern Australia - an overview. Quaternary International, 26, 69-86.

Ortiz J.E., Torres T., Julià R., Delgado A., Llamas F.J., Soler V. \& Delgado J. (2004) - Numerical dating algorithms of amino acid racenization ratios from continental ostracodes. Application to Guadix-Baza basin (southern Spain). Quaternary Science Reviews, 23(5-6), 717-730.

Patacca E. \& Scandone P. (2001) - Late thrust propagation and sedimentary response in the thrust belt-foredeep system of the Southern Apennines (Pliocene-Pleistocene). In: VAI G.B. \& MARTINI I.P. (Eds.), Anathomy of an Orogen: The Apennines and adjacent Mediterranean Basins. Kluwer Academic Publ., 404-440.

Patacca E. \& Scandone P. (2004) - The Plio-Pleistocene thrust beltforedeep system in the Southern Apennines and Sicily (Italy). Special 
Volume Italian Geological Society for the IGC 32 Florence-2004 93-129.

Pérès J.M. (1967) - The Mediterranean benthos. Oceanography Marine Biology Annual Review, 5, 449-553.

Pieri P., Sabato L. \& Tropeano M. (1996) - Significato geodinamico dei caratteri deposizionali e strutturali della Fossa bradanica nel Pleistocene. Memorie Società Geologica Italiana, 51, 501-515.

RicchetTI G. (1967) - Lineamenti geologici e morfologici della media valle del fiume Basento. Bollettino Società Geologica Italiana, 86, 607-622.

Ricchetti G. (1981) - Contributo alla conoscenza della Fossa bradanica $e$ delle Murge. Bollettino Società Geologica Italiana, 99(1980), 421-430.

Ricchetti G., Ciaranfi N., Luperto Sinni E., Mongelli F. \& Pieri P. (1992) - Geodinamica ed evoluzione sedimentaria e tettonica dell'avampaese apulo. Memorie Società Geologica Italiana, 41(1988), 57-82.

Rohling E.J., Marino G. \& Grant K.M. (2015) - Mediterranean climate and oceanography, and the periodic development of anoxic events (sapropels). Earth-Science Reviews, 143, 62-97.

Santoro E., Ferranti L., Burrato P., Mazzella M.E. \& Monaco C. (2013) - Deformed Pleistocene marine terraces along the Ionian Sea margin of southern Italy: Unveiling blind fault-related folds contribution to coastal uplift. Tectonics, 32, 737-762.

SchellmanN G. \& RadtKe U. (2004). A revised morpho- and chronostratigraphy of the Late and Middle Pleistocene coral reef terraces on Southern Barbados (West Indies). Earth-Science Reviews, 64, 157-187.

Schiattarella M., Giano S.I. \& Gtoia D. (2017) - Long-term geomorphological evolution of the axial zone of the CampaniaLucania Apennine, Southern Italy: a review. Geologica Carpathica, 68(1), 57-67.

Stddall M., Rohling E.J., Thompson W.G. \& Waelbroeck C. (2008) Marine Isotope Stage 3 sea level fluctuation: data synthesis and new outlook. Reviews of Geophysics, 46, RG4003, 29 pp.
Torres T., Llamas J., Canotra L., Coello F.J., Garcia Alonso P. \& ORTIZ J.E. (2000) - Aminostratigraphy of two Pleistocene marine sequences from the Mediterranean coast of Spain: Cabo de Huertas (Alicante) and Garrucha (Almeria). In: Goodfriend G.A, Matthew J.C., Marilyn L.F., Stephen A.M., John F.W. (Eds), Perspectives in amino acid and protein geochemistry. Oxford University Press, Oxford, pp. 263-278.

TORRES T., ORTIZ J.E. \& ARRIBAS I. (2013) - Variations in racemization epimerization ratios and amino acid content of Glycymeris shells in raised marine deposits in the Mediterranean. Quaternary Geochronology, 16, 35-49

Tropeano M., Sabato L. \& Pieri P. (2002) - Filling and camibalization of a foredeep: Bradanic Trough, southern Italy. Geological Society London Special Publications, 191, 55-79.

Waelbroeck C., Labeyrie L., Michel E., Duplessy J.C., McManu J.F. Lambeck K., Balbon E. \& Labracherie M. (2002) - Sea-level and deep water temperature changes derived from benthic foraminifera isotopic records. Quaternary Science Reviews, 21, 295-305.

WESTAWAY R. (1993) - Quaternary uplift in Southern Italy. Journal Geophysical Research, 98, 21741-21772.

WESTAWAY R. \& BRIDGLAND D. (2007) - Late Cenozoic uplift of southern Italy deduced from fluvial and marine sediments: coupling between surface processes and lower-crustal flow. Quaternary International, 175, 86-124.

Williamson P.G. (1981) - Palaeontological documentation of speciation in Cenozoic molluscs from Turkana Basin. Nature, 293, 437-443.

Zander A., Fülling M.A., Brückner H. \& Mastronuzzi G. (2006) - OSL dating of Upper Pleistocene littoral sediments: A contribution to the chronostratigraphy of raised marine terraces bordering the Gulf of Taranto, South Italy. Geografia Fisica e Dinamica Quaternaria, 29, 33-50.

Zucca C., Sechi D., Andreucci S., Shaddad S.M., Deroma M., Madrau S., Previtali F., Pascucci V. \& Kapur S. (2014) - Pedogenic and palaeoclimatic evidence from an Eemian calcrete in northwestern Sardinia (Italy). European Journal of Soil Science, $\mathbf{6 5}$ $420-435$. 